\title{
CLIMATE DRIVEN TROPHIC CASCADES AFFECTING SEABIRDS AROUND THE BRITISH ISLES
}

\author{
ALAN MACDONALD ${ }^{1}$, MICHAEL R. HEATH ${ }^{2}$, MARTIN EDWARDS $^{3}$, ROBERT W. \\ FURNESS $^{4}$, JOHN K. PINNEGAR ${ }^{5}$, SARAH WANLESS ${ }^{6}$, DOUGLAS C. SPEIRS ${ }^{7}$, \\ SIMON P.R. GREENSTREET ${ }^{8}$
}

${ }^{1}$ University of Strathclyde, Department of Mathematics and Statistics, Livingstone Tower, 26 Richmond Street, Glasgow G1 1XH, UK, alan.macdonald@strath.ac.uk

${ }^{2}$ University of Strathclyde, Department of Mathematics and Statistics, Livingstone Tower, 26 Richmond Street, Glasgow G1 1XH, UK, m.heath@strath.ac.uk

${ }^{3}$ Sir Alister Hardy Foundation for Ocean Science, The Laboratory, Citadel Hill, Plymouth, PL1 2PB, UK, $\underline{\text { maed@sahfos.ac.uk }}$

${ }^{4}$ Graham Kerr Building, University of Glasgow, Glasgow, G12 8QQ, UK, Bob.Furness@glasgow.ac.uk

${ }^{5}$ Centre for Environment, Fisheries and Aquaculture Science (Cefas), Pakfield Road, Lowestoft, Suffolk, NR33 OHT, UK, john.pinnegar@cefas.co.uk

${ }^{6}$ Centre for Ecology and Hydrology, Bush Estate, Penicuik, EH26 OQB, UK, swanl@ceh.ac.uk 
${ }^{7}$ University of Strathclyde, Department of Mathematics and Statistics, Livingstone Tower, 26

Richmond Street, Glasgow G1 1XH, UK, d.c.speirs@strath.ac.uk

${ }^{8}$ Marine Scotland Science, Marine Laboratory, Aberdeen, AB11 9DB, UK, greenstreet@marlab.ac.uk 
Keywords: pelagic food web, North Sea, trophic interactions, Ammodytes marinus, Calanus finmarchicus, seabird community, regime shift.

\begin{abstract}
After flourishing during the second half of the twentieth century, many North Sea seabird populations are now in decline. Much evidence is accumulating that climate change is driving these negative trends in growth rate. Climate driven changes in the physical environment may affect seabirds both directly and indirectly. Direct impacts such as increasingly common extreme weather events will result in negative physiological responses. However, climate effects on seabirds are more likely to be indirect, and mediated by prey quality and availability. Mounting evidence suggests that climate impacts on lower trophic levels are altering the pathway of energy to seabirds. While the basis for changes in primary production are complex and uncertain, climate driven changes in sandeels, and Calanus finmarchicus, key prey species in adjacent trophic levels, appear to be causing a reduction in breeding success and growth rate in several British seabird species.
\end{abstract}

\title{
Introduction
}

Numbers of many species of seabirds around the UK increased between 1970 and 2000 (Figure 1). However, since the Seabird 2000 census (Mitchell et al. 2004), some of the species have started to decline e.g. Atlantic puffin Fratercula arctica (Harris \& Wanless 2011), northern fulmar Fulmarus glacialis and Great Cormorant Phalacrocorax carbo. Others have continued to increase, for example the common guillemot Uria aalge, razorbill Alca torda, and especially the northern gannet Morus bassanus. In Scotland, northern gannets 
are possibly the only species to increase in the past decade (Wanless \& Harris 2012), and are continuing to form new colonies (Wanless et al. 2005a).

Most surface-feeding seabird species in the northern North Sea have suffered breeding failure since 2003. In Shetland, similar declines in breeding success happened earlier during the 1980s. Large pursuit diving species have not been so affected (Heubeck 1989, Okill 1989). Consequences of such declines in breeding success only become apparent in the population numbers after a considerable time lag as these year-classes of birds mature and join the breeding population (Frederiksen et al. 2004, Mavor et al. 2005, 2006, 2007, Reed et al. 2006).

The overall trends in seabird breeding numbers over recent decades mask some marked regional variations (Figure 2). Significant increases were observed in the breeding numbers of e.g. guillemots, in England and Wales; however the trend was reversed for those breeding in Scotland. Within any one year, some species have bred successfully, and others have not. For a given species, some regions have produced successful breeding and others not. In some cases, a lack of consistency has even been found among species inhabiting the same region (Wanless \& Harris 2012).

Climate change is considered to be playing a significant role in the declines in seabird breeding numbers (Russell et al. 2014). In particular, sea surface temperatures (SST) in UK coastal waters, which have been rising between 0.1 and $0.5^{\circ} \mathrm{C}$ decade ${ }^{-1}$ for the past 30 years (Dye et al. 2013), have shown a strong negative relationship with the demographic rates of several seabird species. For example, the productivity of northern fulmar and black-legged kittiwake Rissa tridactyla on the Scottish east coast shows a negative relationship with SST (Burthe et al. 2014). Furthermore, survival rates of kittiwakes, European shags 
Phalacrocorax aristotelis (Burthe et al. 2014), Atlantic puffins, guillemots, and razorbills (Lahoz-Monfort et al. 2011) are also strongly negatively correlated with SST.

The physical environmental changes which accompany climate change may affect seabirds in a variety of direct and indirect ways. Direct effects include incidences of extreme weather events causing mass mortalities and damage to nests in breeding colonies (Frederiksen et al. 2008a, Wanless \& Harris 2012). Physiological responses to higher temperatures can be expected to cause changes in vital rates for population dynamics (Oswald et al. 2008, 2011). Population dynamics of long-lived seabird species are especially sensitive to adult survival (Lebreton \& Clobert 1991, Saether \& Bakke 2000, Ratcliffe et al. 2002, Furness 2003). Indeed, reduced overwinter survival rates for breeding Atlantic puffins on the Isle of May in 2006-2007 and 2007-2008, combined with an increase in immature mortality (Harris et al. 2013), was sufficient to explain a 30\% reduction in breeding population between 2003 and 2008 (Harris \& Wanless 2011). Synchrony in guillemot survival rates from different colonies around Britain, that share overwintering areas, provides further evidence that climate could be the key determinant of mortality (Reynolds et al. 2011).

In contrast, indirect effects may be mediated through prey quality and availability (Wanless et al. 2005b, Burthe et al. 2012), affecting growth rates and breeding success. These are referred to as bottom-up cascading trophic effects (Carpenter et al. 1985, Pace et al. 1999, Polis et al. 2000, Heath et al. 2014). The aim of this paper is to review and synthesize the evidence for these climate-driven trophic cascade effects on seabirds in waters around the British Isles. In particular the hypothesis that increasing climate-driven changes in phytoplankton and zooplankton have led to a decline since 2000 in the abundance of small planktivorous fish, especially sandeels, and hence to the observed changes in seabird breeding success, frequency of breeding, and increased age of first breeding (Figure 3). We 
approach the matter by addressing the coupling between successive trophic levels in the food web, beginning with the connection between seabirds and fish and working towards lower levels.

\section{Connections between seabirds and fish}

The majority of open-sea bird species around Britain are essentially piscivorous. The prey items brought back to breeding sites by the 26 major seabird species was analysed during the Seabird 2000 survey (1998-2002) (Table 1) and found to consist mostly of sandeels (mainly Ammodytes marinus), small clupeoid fish or zooplankton. Prey were either self-caught or stolen from other birds (Furness 1987, Davis et al. 2005). Exceptions were scavenging species such as northern fulmars and gulls which feed opportunistically and rely partly on discarded fish and offal from vessels (Camphuysen \& Garthe 1997, Furness 2003), and some of the diving species whose diet includes a proportion of seabed organisms (Furness et al. 2012).

There is abundant evidence that fish communities are being affected by climate change. Geographical shifts in the distribution of many shelf-sea fish communities around the British Isles have been well documented. Broadly speaking, these changes can be viewed as a response to warming sea temperatures, so as to maintain individuals in a preferred temperature range (Hedger et al. 2004, Perry et al. 2005, Poulard \& Blanchard 2005, Desaunay et al. 2006, Heath 2007, Dulvy et al. 2008). In some areas, this is manifested as a poleward shift in distribution or a move into deeper water. However, local topography and hydrography may limit the extent of such shifts. 
Poleward shifts in distribution lead to decreases in abundance at the southern edge of the geographic range of a species, and increases at the northern edge (in the northern hemisphere). Temperature-associated species-level changes in abundance which may be accounted for in this way have been identified in 39 of 50 of the most common species in the North Sea (Simpson et al. 2011). Catches of warm-water species, i.e. anchovy $E$.

Encrasicolus, sardine Sardina pilchardus, and striped red mullet Mullus surmuletus, all increased in the North Sea, coinciding with increased temperatures after 1995 (ICES 2007). Moreover, statistical modelling shows northward movements for Atlantic horse mackerel Trachurus trachurus, European anchovy, European sprat Sprattus sprattus, Pollack Pollachius pollachius, Common sole Solea solea, Saithe Pollachius virens and Turbot Scophthalmus maximus between the 1960s and the period 2000-2005 (Lenior et al. 2011). Northward movements for these species, with the exception of Pollack, are predicted to increase substantially under projected IPCC changes in SST (IPCC 2007). Some fish species now inhabit areas where they were absent prior to the 1980s. Examples include anchovy and sardine (Beare et al. 2004a), striped red mullet (Beare et al. 2004b) and bluemouth Helicolenus dactylopterus (Mamie et al. 2007).

Although many of the fish species mentioned above are not directly preyed up on by seabirds, their responses to climate change may be significant to understanding the impacts on birds because they are potential competitors for the main food of piscivorous birds - the common sandeel A. marinus. This species is currently at the southern edge of its latitudinal range around the British Isles (Fishbase 2014), but unlike most other fish species, sandeels are not free to move into deeper waters in response to warming sea temperatures because they are tightly associated with sandy sediments of rather narrow range of grain size composition (Wright et al. 2000, Holland et al. 2005, Greenstreet et al. 2010a). In addition, sandeel stock display a complex spatial population structure which may further limit their capacity to adjust 
their distribution in response to warming. For example, the North Sea stock is composed of seven distinct populations, each exhibiting different population dynamics (Boulcott et al. 2007, ICES 2010, 2013, Boulcott \& Wright 2011). Since 2000, some sandeel populations have undergone a decrease in abundance in parts of the northern North Sea, primarily Shetland and the north-western North Sea (Figure 4), but not in the southern North Sea. The drivers behind patterns of decline in sandeels are complex and may include a combination of climate and fishing impacts.

The decrease in stocks of sandeels in the north-western North Sea since the late 1990's has occurred despite a substantial reduction in fishing activity, suggesting a strong environmental effect. Although larval abundance, and by inference spawning stock biomass, decreased after 2001, recruitment was maintained due to an increasing larval survival rate (Heath et al. 2012). The number of sandeels less than age one around the time of seabird breeding therefore would not have changed dramatically over time, yet the number of older sandeels continued to decline.

Two main factors have been proposed as responsible for the decline in sandeel abundance. Data from chick-feeding Atlantic puffins and Continuous Plankton Recorder samples indicate that the size-at-date of sandeels less than age 1 , hereafter referred to as ' 0 group', has declined substantially since 1973. However, it is unclear what the exact cause of this decline might be (Wanless et al. 2004). A decline in 0-group size-at-date is presumably due to changes in hatch or spawning dates, or changes in growth rate (Frederiksen et al. 2011). However, there is no evidence of trends in hatch dates on the Scottish east coast (Heath et al. 2012a), so the proximate cause for the decline in 0-group size-at-date must be a change in growth rates. 
Alternatively, it is noted that sandeels undergo an overwinter fasting period between late summer and the spawning period in January, during which they remain buried in the seabed in order to evade predation. Individuals show significant weight loss during this period (Boulcott et al. 2007, Boulcott \& Wright 2008), and it is speculated that increased temperature will increase this rate of loss due to elevated metabolism. The energy reserves required to sustain the animals through the winter fast must be accumulated the previous summer, so unless warming is accompanied by increased scope for summer feeding, which does not appear to be the case (Wanless et al. 2004, Boulcott et al. 2007), then the net effect is likely to be reduced overwinter survival (Van Deurs et al. 2011). The recruiting age class in the population, entering its first winter, may be particularly vulnerable to overwintering mortality. Fish older than age 1 usually enter the overwintering period in August and remain buried in the sediment until April the following year emerging only to spawn in January (Winslade 1974). However, many young-of-the-year sandeels may not begin to overwinter until December (Macer 1966, Reeves 1994, Kvist et al. 2001) suggesting that they require extra time to accumulate the necessary energy reserves.

Overwintering mortality may also have played a role in declining sandeel abundances around the Shetland Isles, because sandeels growth rates are much slower at Shetland than elsewhere around Britain (Wright \& Bailey 1993, Bergstad et al. 2002). However, recruitment failure appears to be the more likely cause and increased predation by fish that consume sandeel larvae could explain the decline in this region (Frederiksen et al. 2007). Herring Clupea harengus are known to feed on larval sandeels (Hardy 1924, Last 1989), and stocks of herring have increased from 100,000 tonnes in the late 1970s to 2 million tonnes in 2004 (ICES 2004), in approximately inverse relationship with sandeel abundance around Shetland. Such a mirror-image pattern may indicate a top-down effect of herring predation on sandeel in the northern North Sea. There are precedents for such a phenomenon elsewhere, 
for example herring predation has been implicated in the recruitment variability of Barents Sea capelin Mallotus villosus (Gjøsæter \& Bogstad 1998). However, counter-evidence is that although adult herring biomass has been high since 2000, survival and growth rate of herring larvae has declined (Payne et al. 2009, 2013), which might suggest a common environmental factor affecting both sandeels and herring. Other possible reasons for recruitment failures of the northern sandeel populations are changes in the dispersal patterns of larvae from spawning to settlement sites (Proctor et al. 1998, Christensen et al. 2009), or changes in the phenology of the spring plankton bloom in relation to burial and spawning times of the sandeels (Greenstreet et al. 2006, Scott et al. 2006).

Data from other regions support the idea that a variety of factors may be causing the climate-related changes in sandeel abundances. Recruitment is strongly inversely related to winter temperatures for the sandeel stocks in the central North Sea, especially around Dogger Bank (Arnott \& Ruxton 2002), though the causal mechanism is not known (ICES 2013). In contrast, there is little evidence of direct climate impacts on southern stocks, although changes in growth rates in the southern North Sea have been linked to fluctuations in zooplankton abundance (van Deurs et al. 2014).

Turning to the effects of changes in fish abundance and community composition on seabird populations, the evidence is strikingly clear. Sandeels constitute a significant proportion of the diet for many North Sea seabirds during the breeding season (Wanless et al. 1998, Furness \& Tasker 2000, Furness 2002, Frederiksen et al. 2004, Sandvik et al. 2005, Lahoz-Monfort et al. 2011). Between 1991 and 2011 on the Isle of May sandeels comprised approximately $75 \%$ of the diet of European shag, kittiwake and Atlantic puffins (Newell et al. 2013). Some seabirds, such as kittiwakes and Arctic skuas Stercorarius parasiticus, are highly sensitive to fluctuations in sandeel abundance while others, such as the northern gannet, appear less affected (Furness \& Tasker 2000). The most sensitive seabirds are those 
with high foraging costs, little ability to dive below the sea surface, little 'spare' time in their daily activity budget, short foraging range from the breeding site, and little ability to switch diet (Furness \& Tasker 2000). The well documented declines in breeding productivity of kittiwakes, shags, and Atlantic puffins (Lahoz-Monfort et al. 2013), are highly correlated with the availability of sandeels, especially the older age classes of sandeel (Pinaud \& Weimerskirch 2002, Frederiksen et al. 2006, 2013).

In addition to inter-species variation in the importance of sandeel in the seabird diet, there are also strong regional variations. In northern UK waters sandeels are the only significant prey for seabirds. For example, sandeels have been the only common high-lipid schooling fish around Shetland in recent decades. Breeding success of most seabirds is therefore strongly related to sandeel abundance in that region (Hamer et al. 1993, Davis et al. 2005). Seabirds off south-east Scotland have access to other fish prey, e.g. young herring and sprat (Bull et al. 2004, Harris et al. 2004, Wilson et al. 2004), but sandeels are still the main prey (Wanless et al. 1998). However, in south-western British waters there are higher abundances of alternative prey such as sprat and juvenile herring, so the linkage to sandeel availability is correspondingly weaker. However, it cannot be ruled out that climate change could result in the growth of sprat or juvenile herring populations in northern waters. In fact, a pronounced increase in abundance of European sprat in the North Sea between 2000 and 2005 can be explained by increases in temperature (Lenior et al. 2011). During this time guillemots at Fair Isle, between Orkney and Shetland, underwent a dietary shift (Heubeck 2009), consuming more gadoids and sprat, and fewer sandeels, than previously. Moreover, records on guillemot chick diet composition from the Isle of May in the Firth of Forth indicate that sprat have accounted for the majority of chick diet since 2000 (Anderson et al. 2014). While this is probably a response to lack of sandeels, it is possible that guillemot diet partially reflects their preference for sprat. Indeed, sprat might actually represent a higher 
quality prey resource than sandeels (Smout et al. 2013). For example in 2000 the guillemots at the Firth of Forth switched to sprat even though they were two orders of magnitude less abundant than sandeels (Greenstreet et al. 2010b).

In the north-western North Sea, other potential effects on seabirds arise from the apparent changes in growth rates of sandeels since the 1970's. The decline in size-at-date of the recruiting 0-group stages leads to a mismatch between the timing of seabird breeding and availability of adequate prey. The weight-specific energy content of sandeel is related to their body size, so slower growth rates mean declining calorific content of prey fed to chicks on a given day of the year (Wanless et al. 2004, Burthe et al. 2012). Interestingly, there has been a trend towards later breeding in several species (Burthe et al. 2012), partially mitigating the decline in prey length. Nevertheless, guillemots, shags, kittiwakes, Atlantic puffins and razorbills chicks have all suffered net reductions in energy value because of this decline in sandeel length (Burthe et al. 2012).

In addition to effects on seabird chicks, a lack of 0-group sandeel availability and quality can affect adult seabird mortality, which is particularly influenced by prey availability during the breeding season. This is because seabirds must attain a sufficient level of body energy to meet breeding costs (Oro \& Furness 2002, Ratcliffe et al. 2002). In Shetland, sandeel abundance is related to adult survival of various species, in particular Kittiwake and Great Skua Catharacta skua (Oro \& Furness 2002, Ratcliffe et al. 2002).

Other fish species responding to climate change, may have indirect effects in birds by interfering with the relationship between sandeels and seabirds. This interference may take the form of competition for sandeels as prey (Greenstreet et al. 2010b), or presenting as an abundant but less nutritious alternative prey. The much-reported influx of snake pipefish Entelurus aequoreus into European waters in 2003 (Lindley et al. 2006, Harris et al. 2008, Kloppmann \& Ulleweit 2007, van Damme \& Couperus 2008) represents an example of the 
latter. Trawl survey records show catches of snake pipefish began to increase in 2003 off north-west Scotland, and had covered the entire North Sea by 2007 (Figure 5). Catches declined sharply in 2009. A simultaneous population explosion and subsequent contraction happened in the Barents Sea (Høines et al. 2009). It is unclear why snake pipefish numbers increased. However, Continuous Plankton Recorder samples show that high numbers of larval and juvenile stages extended as far west as the Mid-Atlantic Ridge, and may have coincided with a rise in sea temperatures between January and September, when the eggs are developing and the larvae are growing in the plankton (Kirby et al. 2006). Alternatively, a shift in zooplankton species composition may have helped facilitate the explosion of pipefish numbers (van Damme \& Couperus 2008).

In 2003, snake pipefish began to appear in the diet of several seabird species (Anderson et al. 2014, Harris et al. 2007). We do not know if seabirds mistook pipefish for their usual prey, or whether they were capturing them because sandeels and clupeoid fish were in short supply. In either case, the pipefish represented a poor quality resource; low in lipid, bony and difficult to digest (Harris et al. 2008). Previous work has shown that most seabird colonies have less successful breeding years when chicks are fed on prey with lower than average energy content (Wanless et al. 2005b).

\section{Connections between fish and zooplankton}

The principal role of zooplankton in the food web is as a vector for transferring primary production to fish. Sandeels, are likely to be bottom-up limited by zooplankton abundance (Frederiksen et al. 2006). In particular, the crucial larval stage, is more likely to be affected by bottom-up effects through the plankton (Pitois et al. 2012). 
During the 1980s the North Sea ecosystem underwent a regime shift that resulted in pronounced changes to the fish and plankton community composition (Beaugrand 2004). These changes have been ascribed to increased sea temperature (Beaugrand et al. 2002, Perry et al. 2005). Moreover, recent decades have seen pronounced northward shifts in the range of calanoid copepods (Reid et al. 1998, 2001, Beaugrand et al. 2002, Drinkwater et al. 2003, Reygondeau \& Beaugrand 2011). The mean rate of northward movement for some northeastern North Atlantic species assemblages between 1958 and 2005 has been estimated at roughly $23 \mathrm{~km} \mathrm{yr}^{-1}$ (Beaugrand et al. 2009). During this time, the critical threshold separating boreal and temperate zooplankton systems has moved forward by $22 \mathrm{~km} \mathrm{yr}^{-1}$ (Beaugrand et al. 2008).

The calanoid copepod, Calanus finmarchicus, is currently vital in the diet of sandeel larvae as larval survival depends specifically on the abundance of $C$. finmarchicus, not overall Calanus spp., or C. helgolandicus (van Deurs et al. 2009). However, despite being previously dominant in the North Sea, $C$. finmarchicus, has declined in biomass by $70 \%$ since the 1960s. Species with warmer-water affinities (e.g. C. helgolandicus) are moving northward to replace this species but these species are not as numerically abundant or nutritionally beneficial (lower lipid contents) to higher trophic levels. Moreover, recent temperature increases have reduced the size of zooplankton. Declines in sandeel length have been linked with these changes (van Deurs et al. 2014). A time series of sandeel length at age in the southern North Sea shows a decrease in the late 1980s, around the time when the mean size of calanoid copepods decreased by a factor of two (Beaugrand et al. 2003). This decrease in copepod size was an effect of the regime shift that took place in the North Sea in the late 80s, caused by a switch in the NAO index from a negative to positive phase (Reid et al. 2001, Beaugrand et al. 2002, 2003, Beaugrand \& Reid 2003, Beaugrand 2004). 
Despite the documentation of changes in species distribution, there is little clear evidence of changes in overall zooplankton production in the North Sea. Trends in zooplankton production on the Scottish east coast do not reflect the pattern of decline in sandeels (Heath et al. 2012, O'Brien et al. 2013). Apart from changes in zooplankton abundance, changes in seasonality (van Deurs et al 2009), size (Beaugrand et al. 2003) and lipid content of zooplankton (Wanless et al 2005b, Beaugrand et al 2009) could all affect sandeel populations. Zooplankton community production is exceptionally difficult to estimate, even by direct experimental measurements, and certainly from just data on species abundances.

Northward shifts of plankton species are expected to continue with increasing sea temperatures (Reygondeau \& Beaugrand 2011). How these changes will affect higher trophic levels remains unclear. However, it is thought that the retreat of $C$. finmarchicus will be damaging to sandeel populations (van Deurs et al. 2009), and ultimately seabirds (Frederiksen et al. 2013). A recent niche model study (Frederiksen et al. 2013) showed that the breeding success of kittiwakes and Atlantic puffins on the Isle of May is significantly related to environmental suitability for $C$. finmarchicus (van Deurs et al. 2009). Therefore, it may become increasingly difficult for several boreal seabird species to maintain adequate breeding success as this Calanus species continues its retreat.

The future of sandeels in the North Sea will rest on whether a suitable replacement prey can be found with the most viable candidate being $C$. helgolandicus. However, $C$. finmarchicus abundance peaks in spring (Bonnet et al. 2005) concurrently with mean larval hatch date (Heath et al. 2012), whereas C. helgolandicus abundance peaks in autumn (Bonnet et al. 2005). Therefore, a mismatch between larval emergence and prey availability may occur if $C$. helgolandicus becomes the dominate prey species for sandeels. 
Geographical shifts in plankton species can be related to environmental changes (Beaugrand \& Helaouët 2008). We can have reasonable confidence in such predictions for different climate change scenarios, subject to the assumption that the underlying processes governing the ecological niche will remain constant in the future (Davis et al. 1998, Pearson \& Dawson 2003). In addition, we can be quite confident that the zooplankton diversity in UK waters will increase with continued warming (Beaugrand et al. 2008), with a progressive shift towards smaller-sized plankton. Moreover, we can speculate that a shift towards smaller zooplankton may lead to reductions in trophic transfer efficiency due to increased food chain length.

Ocean modeling predicts a reduction in zooplankton biomass in the North Sea over the next century (Chust et al. 2014). These changes are thought to arrive via bottom up amplification of negative climate-driven impacts on phytoplankton (Chust et al. 2014). Therefore, it is important to understand how climate change may affect zooplankton indirectly through changes in primary production.

\section{Connections between zooplankton and phytoplankton}

The production of zooplankton, fish and higher trophic levels in the marine ecosystem must ultimately be related to primary production, and the efficiency of transfer between trophic levels (Aebischer et al. 1990, Schwartzlose et al. 1999, Chavez et al. 2003). Hence, comparing across ecosystems in the north-western Atlantic, there is a positive correlation between long-term average chlorophyll concentration and fishery yield (Frank et al. 2005). In the case of sandeels, it is clear that primary production drives stock biomass in some ecosystems (Eliasen et al. 2011). However, within individual ecosystems the relationships over time between primary production and fisheries yield varies depending on a range of 
factors affecting the transfer of energy up the food web and the intensity of exploitation of the fish stocks.

Overall phytoplankton biomass in the North Sea has increased in recent decades (Edwards et al. 2001); and there has been a concurrent increase in smaller flagellates that are promoted by warmer and more stratified conditions (Edwards \& Richardson 2004). Over the whole north-east Atlantic, there has been an increase in phytoplankton biomass with increasing temperatures in cooler regions, but a decrease in phytoplankton biomass in warmer regions (Barton et al. 2003). However, nutrient concentrations are likely to limit any positive response to warming (O’Brien et al. 2012).

Over multi-decadal periods in the North Atlantic, changes in phytoplankton species and communities have been associated with temperature trends and variations in the NAO index (Beaugrand \& Reid 2003). These changes have included the occurrence of sub-tropical species in temperate waters, changes in overall phytoplankton biomass and seasonality, changes in the ecosystem functioning and productivity of the North Atlantic (Beaugrand 2004, Edwards et al. 2001).

Unfortunately it is only possible to speculate on how climate change may indirectly impact zooplankton through changes in phytoplankton. For example, we can speculate that climate driven changes in phytoplankton and zooplankton phenology (Edwards \& Richardson 2004) may reduce prey availability for zooplankton. The key point is clear evidence that changes in climate have already impacted phytoplankton, resulting in zooplankton changes, remains thin. 


\section{Discussion}

There is much evidence to suggest climate-driven trophic cascades have already affected seabirds in the waters around the British Isles. Whilst the basis for changes being driven by primary production are complex and uncertain, there is growing evidence of direct climate impacts on zooplankton and the immediate prey of seabirds. The key route of energy transfer to many of the main seabird species is through $C$. finmarchicus and A. marinus. Climate change is disrupting this pathway of energy transfer and appears to be causing a decline in breeding success and survival of several important UK seabirds, primarily those in northern areas e.g. Scottish east coast.

In the short term we can predict with reasonable confidence that the recent succession of poor breeding years will propagate through seabird populations to cause a decline in breeding numbers. Beyond this, changes will depend on the balance between breeding success, maturation rate and adult survival. The future patterns of seabird breeding maturation and survival may depend critically on the scope for feeding on alternative prey, if sandeel stocks do not recover over time with continued warming. However, the strength of resilience to food shortages may vary among species. For example, kittiwakes are sensitive to reductions in sandeel availability (Furness \& Tasker 2000) while adult guillemots seem able to maintain provisioning of their chicks despite fluctuating abundances of key prey (Smout et al. 2013). Inter species variation in sensitivity to reductions in sandeel abundance may explain why climate effects appear to be species-specific (Lahoz-Monfort et al. 2011), assuming that sandeel abundance is negatively correlated with climate indices. Winter NAO and SST are contributing to synchrony, as well as desynchrony in survival rates of auks off the Scottish east coast (Lahoz-Monfort et al. 2011). 
Continued decline in sandeel quality and abundance may cause the North Sea seabird community to become increasingly dominated by species least reliant on sandeels (Furness and Tasker 2000). An example of this may be the northern gannet, which has prospered in recent decades (Wanless et al. 2005a, Murray et al. in press). These birds are very insensitive to reductions in sandeel availability, owing in part to their high ability to switch diet (Furness and Tasker 2000). Northern gannets are also the largest seabirds in the North Atlantic. Therefore, a trend towards a seabird community dominated by larger seabirds contrasts strongly with observed trends in prey length in lower trophic levels.

The regional pattern of decline in seabird numbers is strikingly similar to the decline in sandeel populations. Regional differences in the strength of bottom-up regulation may provide an explanation. In the Irish Sea, Celtic Sea and the English Channel, there appears to be little evidence of bottom-up regulation (Lauria et al. 2013). However, bottom-up effects have been found to exist in the north-western North Sea (Frederiksen et al. 2006), which could be diagnostic of different oceanographic conditions (Lauria et al. 2013). Climate change impacts on lower trophic levels may therefore affect seabird numbers in the northern North Sea but have little effect on seabirds in southern areas.

While the predicted short-term increase in sprat abundance around Britain in response to warming (Lenior et al. 2011) may mitigate a shortage of sandeels, they probably do not represent a long-term solution for seabirds. Sprat are predicted to disappear from these waters by the end of this century, with the distribution shifting to the Barents Sea (Lenior et al. 2011). In fact, warm-water mid-trophic fish such as anchovies (Lenoir et al. 2011) will likely be performing the role in the ecosystem vacated by sandeels and sprat. Although these fish could potentially fill the void left by sprat and sandeels in seabird diets, whether or not there will be a smooth transition in prey is unknown. Consistent recruitment failure of herring (Payne et al. 2009, 2013) places in doubt the viability of this species as alternative prey for 
seabirds. Many seabirds are able to prey on piscivorous demersal fish like whiting Merlangius merlangus, but these have a very low energy density and the body condition of chicks is much poorer in years where whiting are the main prey (Harris 1980).

In the case of seabirds that feed opportunistically by scavenging at fishing vessels (especially great skuas, northern fulmars, great black-backed gulls Larus marinus) part of the impact on their breeding success may be due to reduced amounts of fishery discards and offal in recent years (Votier et al. 2004, 2007, Käkelä et al. 2005, 2007, Furness 2006, 2007). Although these seabirds prefer to feed by on sandeels, they turn to fishery offal and discards as an alternative food, and in the last few years there have been large reductions in amounts of discards and offal provided to seabirds all around Britain at a time when sandeels have also declined. Great skuas have attempted to mitigate this situation by increasingly killing other seabirds, but have also suffered breeding failures due to food shortage, part of which results from the fact that great skuas will kill chicks of neighbouring skua pairs. The depredations on other seabirds will also reduce their breeding success, as the chances of chicks surviving if a parent has been killed during the breeding season will be much reduced. Although gannets mainly feed on pelagic fish in summer, discards at fishing vessels makes up a significant component of the diet in winter. A trend for gannets to be moving further south in winter than they did previously may be related to reductions in discarding (Kubetzki et al. 2009).

In 2014, the EU common fisheries policy was reformed to include a complete ban on fishing discards. A ban on discards of pelagic species will be enforced in January 2015, with the ban extending to the most valuable demersal species (cod, hake and sole) in 2016, and all total allowable catch species in 2019 (European Commission, 2013). This will almost certainly have a major impact on many seabird populations throughout Europe that are, at the moment, 
reliant on discards. Species native to the north-east Atlantic that are currently extensively exploiting fishery discards are kittiwakes, herring gulls Larus argentatus, the lesser blackbacked gull Larus fuscus, the great black-backed gull, the great skua, the northern fulmar and the northern gannet (Bicknell et al. 2013). We can speculate that the cessation in discards could slow the sustained growth in gannet populations.

Evidence suggests that anthropogenic and climate impacts on seabirds could be additive (Frederiksen et al. 2004, Votier et al. 2005). On the Scottish east coast, the species most vulnerable to these combined threats are northern fulmars, kittiwakes, and shags (Burthe et al. 2014). The vital rates (e.g. growth, maturation and survival rates) of these species have been decreasing with rising temperature, most likely through changes in prey e.g. sandeels. To ameliorate any declines in these demographic parameters, efforts to safeguard vital seabird prey around important colonies, such as the Isle of May, could be put in place. The most notable case is the sandeel fishery closure off the east coast of Scotland in 2000. Established with the aim of avoiding depletion of the sandeel stock, a substantial area covering approximately $21,000 \mathrm{~km}^{2}$ was closed to sandeel fisheries (Frederiksen et al. 2008b, Greenstreet et al. 2010b). However, closing off the area to fishing has not been sufficient to ensure high sandeel abundance (Figure 4). Recent measures have been enforced to protect seabird adjacent marine habitats. In 2009, 31 of Scotland's seabird breeding colony Special Protection Areas (SPAs) were extended (http://www.snh.org.uk/about/directives/abdir15j.asp), however, the marine areas protected are extremely small $(<5 \mathrm{~km})$ and therefore may not effectively safeguard seabird prey. This is especially true for sandeel feeding seabirds because of the patchiness of sandeel habitat. Moreover, many seabirds have foraging ranges that span many tens of kilometres (Thaxter et al. 2012). In addition to protecting sandeel prey in the vicinity of seabird colonies, measures to protect sources of sandeel larvae 
that are exported to these areas can also be put in place. Recently marine protected areas in north-west Orkney and Turbot bank have been established with the aim of protecting sandeel larvae (http://jncc.defra.gov.uk/page-6484, http://jncc.defra.gov.uk/page-6490). These location were chosen as they are thought to be important sources of newly hatched sandeel larvae (Wright \& Bailey 1996) which, through dispersal, support populations afar. It is possible that MPAs may lead to increased abundance outwith the MPA caused by larval spillover (Christensen et al. (2009). However, the extent of spillover will obviously depend on availability of suitable habitat.

\section{Conclusions}

We summarize our key findings from this review as follows:

- Climate-driven trophic cascades are already affecting seabirds in UK waters.

- There appears to be marked inter-species variation in sensitivity to climate change. 
- Strong regional differences exist in climate effects on seabirds, possibly due to spatial variation in prey affecting the strength of bottom-up effects.

- Winter temperature appears to be having a negative impact on sandeel populations in the north-western North Sea. These populations are characterised by low growth rates so metabolic costs of overwintering should increase with rising temperatures.

- A reduction in mean copepod size may explain a long term decline in sandeel size-atdate. This ongoing reduction in sandeel size-at-date is causing a mismatch between seabird peak energy requirements and adequate sandeel prey.

- C. finmarchicus is a key prey species of sandeel so we should expect further deleterious impacts on sandeels in future in response to the ongoing northward shift of this Calanus species. This will have the effect of a reduction in seabird breeding success.

- There is no evidence of indirect climate impacts on zooplankton through changes in phytoplankton. Therefore, any indirect climate impacts on seabirds may be restricted to changes in fish prey or zooplankton.

- Future patterns of sandeel-dependent seabird breeding maturation and survival will depend critically on the scope for feeding on alternative prey.

- An increase in sprat abundance should temporarily mitigate the impact of a shortage of sandeels for some seabirds. However, existing modelling indicates that they may not represent a long-term solution.

- Declines in sandeel quality and abundance could cause the North Sea seabird community to become increasingly dominated by larger species. 


\section{References}

Aebischer, N.J., Coulson, J.C. \& Colebrook, J.M. 1990. Parallel long-term trends across four marine trophic levels and weather. Nature 347, 753-755.

Alerstam, T. 1990. BIRD MIGRATION. Cambridge: Cambridge University Press.

Anderson, H.B., Evans, P.G.H., Potts, J.M., Harris, M.P. \& Wanless, S. 2014. The diet of Common Guillemot (Uria aalge) chicks at colonies in the UK, 2006-2011: evidence for changing prey communities in the North Sea. Ibis 156, 23-34.

Arnott, S.A. \& Ruxton, G.D. 2002. Sandeel recruitment in the North Sea: demographic, climatic and trophic effects. Marine Ecology Progress Series 238, 199-210.

Arrhenius, F. 1997. Top-down controls by young-of-the-year herring (Clupea harengus) in the northern Baltic proper. In Forage fishes in marine ecosystems. University of Alaska, Fairbanks: Sea Grant College Program AK-SG-97-01, 77-86.

Balmer, D.E., Peach, W.J. 1997. Review of Natural Avian Mortality Rates. Norfolk: BTO Research Reports.

Barton, A.D., Greene, C.H., Monger, B.C. \& Pershing, A.J. 2003. The Continuous Plankton Recorder survey and the North Atlantic Oscillation: Interannual-to Multidecadal-scale patterns of phytoplankton variability in the North Atlantic Ocean. Progress in Oceanography 58, 337-358.

Beare, D.J., Burns, F., Peach, K., Portilla, E., Greig, A., McKenzie, E. \& Reid, D.G. 2004a. An increase in the abundance of anchovies and sardines in the north-western North Sea since 1995. Global Change Biology 10, 1209-1213.

Beare, D.J., Burns, F., Peach, K. \& Reid, D.G. 2004b. Red mullet migration into the northern North Sea during late winter. Journal of Sea Research 53, 205-212.

Beaugrand, G. 2004. The North Sea regime shift: evidence, causes, mechanisms and consequences. Progress in Oceanography 60, 245-262. 
Beaugrand, G., Brander, K.M., Lindley, J.A., Souissi, S. \& Reid, P.C. 2003. Plankton effect on cod recruitment in the North Sea. Nature 426, 661-664.

Beaugrand, G., Edwards, M., Brander, K., Luczak, C. \& Ibanez, F. 2008. Causes and projections of abrupt climate-driven ecosystem shifts in the North Atlantic. Ecology Letters 11, 1157-1168.

Beaugrand, G. \& Helaouët, P. 2008. Simple procedures to assess and compare the ecological niche of species. Marine Ecology Progress Series 363, 29-37.

Beaugrand, G., Luczak, C. \& Edwards, M. 2009. Rapid biogeographical plankton shifts in the North Atlantic Ocean. Global Change Biology 15, 1790-1803.

Beaugrand, G. \& Reid, P.C. 2003. Long-term changes in phytoplankton, zooplankton and salmon related to climate. Global Change Biology 9, 801-817.

Beaugrand, G., Reid, P.C., Ibanñez, F., Lindley, J.A. \& Edwards, M. 2002. Reorganization of North Atlantic marine copepod biodiversity and climate. Science 296, 1692-1694.

Becker, P.H. \& J.-D. Ludwigs. 2004. Sterna hirundo Common Tern. BWP Update 6, 93 139.

Bergstad, O.A., Høines, A.S. \& Jørgensen, T. 2002. Growth of sandeel, Ammodytes marinus, in the northern North Sea and Norwegian coastal waters. Fisheries Research 56, 923.

Bicknell, A.W.J., Oro, D., Camphuysen, C.J. \& Votier S.C. 2013. Potential consequences of discard reform for seabird communities. Journal of Applied Ecology 50, 649-658.

Bonnet, D., Richardson, A.J., Harris, R., Hirst, A., Beaugrand, G., Edwards, M., Ceballos, S., Diekman, R., López-Urrutia, A., Valdes, L., Carlotti, F., Molinero, J.C., Weikert, H., Greve, W., Lucic, D., Albaina, A., Yahia, N.D., Umani, S.F., Miranda, A., Santos, A., Cook, K., Robinson, S. \& Fernandez de Puelles, M.L. 2005. An overview of Calanus helgolandicus ecology in European waters. Progress in Oceanography 65, 1-53. 
Boulcott, P. \& Wright, P.J. 2008. Critical timing for reproductive allocation in a capital breeder: evidence from sandeels. Aquatic Biology 3, 31-40.

Boulcott, P., Wright, P.J., Gibb, F.M., Jensen, H. \& Gibb, I.M. 2007. Regional variation in maturation of sandeels in the North Sea. ICES Journal of Marine Science 64, 369376.

Boulcott, P. \& Wright, P.J. 2011. Variation in fecundity in the lesser sandeel: implications for regional management. Journal of the Marine Biological Association of the United Kingdom 91, 1273-1280.

Brooke, M. 1990. THE MANX SHEARWATER. London: Poyser.

Buckcicinski, D.B. \& Buckcicinska, M.B. 2003. In The Journal of the Birds of the Western Palearctic Vol.5, D. Parkin (ed.). Oxford: Oxford University Press, 13-39.

Bull, J., Wanless, S., Elston, D.A., Daunt, F., Lewis, S. \& Harris, M.P. 2004. Local-scale variability in the diet of Black-legged Kittiwakes Rissa tridactyla. Ardea 92, 43-52.

Burthe, S., Daunt, F., Butler, A., Elston, D.A., Frederiksen, M., Johns, D., Newell, M., Thackeray, S.J. \& Wanless, S. 2012. Phenological trends and trophic mismatch across multiple levels of a North Sea pelagic food web. Marine Ecology Progress Series 454, 119-133.

Burthe, S.J., Wanless, S., Newell, M.A., Butler, A. \& Daunt, F. 2014. Assessing the vulnerability of the marine bird community in the western North Sea to climate change and other anthropogenic impacts. Marine Ecology Progress Series 507, 277295.

Camphuysen, C.J. \& Garthe, S. 1997. An evaluation of the distribution and scavenging habits of northern fulmars (Fulmarus glacialis) in the North Sea. ICES Journal of Marine Science 54, 654-683. 
Carpenter, S.R., Kitchell, J.F. \& Hodgson, J.R. 1985. Cascading trophic interactions and lake productivity. Biosciences 35, 634-639.

Chabrzyk, G. \& Coulson, J.C. 1976. Survival and recruitment in the herring gull Larus argentatus. Journal of Animal Ecology 45, 187-203.

Chapdelaine, G. 1997. Pattern of recoveries of banded Razorbills ( Alca torda) in the western Atlantic and survival rates of adults and immatures. Colonial Waterbirds 20, 47-54.

Chavez, F.P., Ryan, J., Lluch-Cota, S.E. \& Niqeun, M.C. 2003. From anchovies to sardines and back: multidecadal change in the Pacific Ocean. Science 299, 217-221.

Christensen, A., Mosegaard, H. \& Jensen, H. 2009. Spatially resolved fish population analysis for designing MPAs: influence on inside and neighbouring habitats. ICES Journal of Marine Science 66, 56-63.

Chust, G., Allen, J.I., Bopp, L., Schrum, C., Holt, J., Tsiaras, K., Zavatarelli, M., Chifflet, M., Cannaby, H., Dadou, I., Daewel, U., Wakelin, S.L., Machu, E., Pushpadas, D., Butenschon, M., Artioli, Y., Petihakis, G., Smith, C., Garçon, V., Goubanova, K., Le Vu, B., Fach, B.A., Salihoglu, B., Clementi, E. \& Irigoien, X. 2014. Biomass changes and trophic amplification of plankton in a warmer ocean. Global Change Biology 20, $2124-2139$.

Clobert, J., Lebreton, J.D., Allainé, D. \& Gaillard, J.M. 1994. The estimation of age-specific breeding probabilities from capture or resightings in vertebrate populations. II. Longitudinal models. Biometrics 50, 375-387.

Corten, A. 2001. Northern distribution of North Sea herring as a response to high water temperatures and/or low food abundance. Fisheries Research 50, 189-204.

Coulson, J.C. \& Horobin, J. 1976. The influence of age on the breeding biology of the Arctic tern Sterna paradisaea. Journal of Zoology 178, 247-260. 
Coulson, J.C. \& White, E. 1959. The Post-Fledging Mortality of the Kittiwake. Bird Study 6, 97-102.

Cramp, S. (ed.). 1977. Family Phalacrocoracidae cormorants, shags. In Handbook of the birds of Europe the Middle East and North Africa, vol. 1. Oxford: Oxford University Press, 199-222.

Cramp, S. et al. (eds.). 1977-94. BIRDS OF THE WESTERN PALEARCTIC. Oxford: Oxford University Press.

Cramp, S., Bourne, W.R.P. \& Sanders, D. 1974. THE SEABIRDS OF BRITAIN AND IRELAND. London: Collins.

Cramp, S. \& Simmons, K.E.L. (eds.) 1983. THE BIRDS OF THE WESTERN PALEARCTIC. Vol. III. Oxford: Oxford University Press.

Davis, A.J., Jenkinson, L.S., Lawton, J.H., Shorrocks, B. \& Wood, S. 1998. Making mistakes when predicting shifts in species range in response to global warming. Nature 391, $783-786$.

Davis, S.E., Nager, R.G. \& Furness, R.W. 2005. Food availability affects adult survival as well as breeding success of parasitic jaegers. Ecology 86, 1047-1056.

Desaunay, Y., Guerault, D., Le Pape, O. \& Poulard, J.-C. 2006. Changes in occurrence and abundance of northern/southern flatfishes over a 20 -year period in a coastal nursery area (Bay of Vilaine) and on the eastern continental shelf of the Bay of Biscay. Scientia Marina 70, 193-200.

Drinkwater, K.F., Belgrano, A., Borja, A., Conversi, A., Edwards, M., Greene, C.H., Ottersen, G., Pershing, A.J. \& Walker, H. 2003. The response of marine ecosystems to climate variability associated with the North Atlantic Oscillation in The North Atlantic Oscillation: climatic significance and environmental impact, Geophysical Monograph 134, 211-234. 
Dulvy, N.K., Rogers, S.I., Jennings, S., Stelzenmüller, V., Dye, S.R. \& Skjoldal, H.R. 2008. Climate change and deepening of the North Sea fish assemblage: a biotic indicator of warming seas. Journal of Applied Ecology 45, 1029-1039.

Dunnet, G.M. \& Ollason, J.E. 1978a. Survival and longevity in the Fulmar. Ibis 120, 124125.

Dunnet, G.M. \& Ollason, J.C. 1978b. The Estimation of Survival Rate in the Fulmar, Fulmarus glacialis . Journal of Animal Ecology 47, 507-520.

Dye, S.R., Hughes, S.L., Tinker, J., Berry, D.I., Holliday, N.P., Kent, E.C., Kennington, K., Inall, M., Smyth, T., Nolan, G., Lyons, K., Andres, O. \& Beszczynska-Möller, A. 2013. Impacts of climate change on temperature (air and sea). MCCIP Science Review 2013, 1-12, doi:10.14465/2013.arc01.001-012

Edwards, M., Reid, P. \& Planque, B. 2001. Long-term and regional variability of phytoplankton biomass in the Northeast Atlantic (1960-1995). ICES Journal of Marine Science 58, 39-49.

Edwards, M. \& Richardson, A.J. 2004. Impact of climate change on marine pelagic phenology and trophic mismatch. Nature 430, 881-884.

Eliasen, K., Reinert, J., Gaard, E., Hansen, B., Jacobsen, J.A., Grønkjær, P. \& Christensen, J.T. 2011. Sandeel as a link between primary production and higher trophic levels on the Faroe shelf. Marine Ecology Progress Series 438, 185-194.

European Commission. 2013. Proposal for a new regulation on the common fisheries policy. http://ec.europa.eu/fisheries/reform/proposals/index_en.htm (accessed 15th October 2014).

Ewins, P.J. 1988. An analysis of ringing recoveries of Black Guillemots Cepphus grylle in Britain and Ireland. Ringing \& Migration 9, 95-102.

Fishbase. 2014. http://www.fishbase.org/summary/37 (accessed 30th June 2014). 
Frank, K.T., Petrie, B., Choi, J.S. \& Leggett, W.C. 2005. Trophic cascades in a formerly coddominated ecosystem. Science 308, 1621-1623.

Frederiksen, M., Anker-Nilssen, T., Beaugrand, G. \& Wanless, S. 2013. Climate, copepods and seabirds in the boreal Northeast Atlantic - current state and future outlook. Global change biology 19, 364-372.

Frederiksen, M. \& Bregnballe, T. 2000. Evidence for density-dependent survival in adult cormorants from a combined analysis of recoveries and resightings. Journal of Animal Ecology 69, 737-752.

Frederiksen, M., Daunt, F., Harris, M.P. \& Wanless, S. 2008a. The demographic impact of extreme events: stochastic weather drives survival and population dynamics in a longlived seabird. Journal of Animal Ecology 77, 1020-1029.

Frederiksen, M., Edwards, M., Richardson, A.J., Halliday, N.C. \& Wanless, S. 2006. From plankton to top predators: bottom-up control of a marine food web across four trophic levels. Journal of Animal Ecology 75, 1259-1268.

Frederiksen, M., Elston, D.A., Edwards, M., Mann, A.D. \& Wanless, S. 2011. Mechanisms of long-term decline in size of lesser sandeels in the North Sea explored using a growth and phenology model. Marine Ecology Progress Series 432, 137-147.

Frederiksen, M., Furness, R.W. \& Wanless, S. 2007. Regional variation in the role of bottomup and top-down processes in controlling sandeel abundance in the North Sea. Marine Ecology Progress Series 337, 279-286.

Frederiksen, M., Jensen, H., Duant, F., Mavor, R.A. \& Wanless, S. 2008b. Differential effects of a local industrial sand lance fishery on seabird breeding performance. Ecological Applications 18, 701-710.

Frederiksen, M. \& Petersen, A. 1999. Adult Survival of the Black Guillemot in Iceland. Condor 101, 589-597. 
Frederiksen, M., Wanless, S., Harris, M.P., Rothery, P. \& Wilson, L.J. 2004. The role of industrial fisheries and oceanographic change in the decline of North Sea blacklegged kittiwakes. Journal of Applied Ecology 41, 1129-1139.

Furness, R.W. 1984. Leach's petrel populations on St Kilda. British Ecological Society Bulletin 15, 84-87.

Furness, R.W. 1987. THE SKUAS. London: T. \& A.D. Poyser.

Furness, R.W. 2002. Management implications of interactions between fisheries and sandeeldependent seabirds and seals in the North Sea. ICES Journal of Marine Science 59, $261-269$.

Furness, R.W. 2003. Impacts of fisheries on seabird communities. Scientia Marina 67, 3345.

Furness, R.W. 2006. How many fish should we leave in the sea for seabirds and marine mammals? In Top Predators in Marine Ecosystems: Their Role in Monitoring and Management, I. Boyd et al. (eds). Cambridge: Cambridge University Press, 211-222.

Furness, R.W. 2007. Responses of seabirds to depletion of food fish stocks. Journal of Ornithology 148, 247-252.

Furness, R.W. \& Tasker, M.L. 2000. Seabird-fishery interactions: quantifying the sensitivity of seabirds to reductions in sandeel abundance, and identification of key areas for sensitive seabirds in the North Sea. Marine Ecology Progress Series 202, 253-264.

Furness, R.W., Wade, H.M., Robbins, A.M.C. \& Masden, E.A. 2012. Assessing the sensitivity of seabird populations to adverse effects from tidal stream turbines and wave energy devices, supplementary material. ICES Journal of Marine Science $\mathbf{6 9}$, $1466-1479$. 
Gjøsæter, H. \& Bogstad, B. 1998. Effects of the presence of herring (Clupea harengus) on the stock-recruitment relationship of Barents Sea capelin (Mallotus villosus). Fisheries Research 38, 57-71.

Greenstreet, S., Fraser, H., Armstrong, E. \& Gibb, I. 2010b. Monitoring the consequences of the northwestern North Sea sandeel fishery closure. Scottish Marine and Freshwater Science 1, 1-31.

Greenstreet, S.P.R., Holland, G.J., Guirey, E.J., Armstrong, E., Fraser, H.M. \& Gibb, I.M. 2010a. Combining hydroacoustic seabed survey and grab sampling techniques to assess "local" sandeel population abundance. ICES Journal of Marine Science 67, 971-984.

Greenstreet, S.P.R., Robertson, M., Fraser, H., Holland, G., Doyle, K. \& Li, R. 2006. Variation in the abundance, distribution, diet and food consumption rates of gadoid predators in the Wee Bankie/Marr Bank region of the northwestern North Sea, and consequences for predator population dynamics. EU-IMPRESS Final Report Appendix 8.65pp.

Hamer, K.C., Monaghan, P., Uttley, J.D., Walton, P. \& Burns, M.D. 1993. The influence of food supply on the breeding ecology of Kittiwakes Rissa tridactyla in Shetland. Ibis 135, 255-263.

Hardy, A.C. 1924. The herring in relation to its animate environment. Part 1. The food and feeding habits of the herring with special reference to the east coast of England. Fishery Investigations London Series II 7, 1-53.

Harris, M.P. 1970. Rates and causes of increase of some British gull populations. Bird Study 17, 325-335.

Harris, M.P. 1980. Breeding performance of puffins fratercula artica in relation to nest density, laying date and year. Ibis 122, 193-209. 
Harris, M.P. 1983. Biology and survival of the immature puffin Fratercula arctica . Ibis 125, 56-73.

Harris, M.P., Buckland, S.T., Russell, S.M. \& Wanless, S. 1994. Year- and Age-Related Variation in the Survival of Adult European Shags over a 24-Year Period. The Condor 96, 600-605.

Harris, M.P., Daunt, F., Bogdanova, M.I., Lahoz-Monfort, J.J., Newell, M.A., Phillips, R.A. \& Wanless, S. 2013. Inter-year differences in survival of Atlantic puffins Fratercula arctica are not associated with winter distribution. Marine Biology 160, 2877-2889.

Harris, M.P., Frederiksen, M. \& Wanless, S. 2007. Within and between-year variation in the juvenile survival of Common Guillemots Uria aalge. Ibis 149, 472-481.

Harris, M.P., Freeman, S.N., Wanless, S., Morgan, B.J.T. \& Wernham, C.V. 1997. Factors Influencing the Survival of Puffins Fratercula arctica at a North Sea Colony over a 20-Year Period. Journal of Avian Biology 28, 287-295.

Harris, M.P., Newell, M., Daunt, F., Speakman, J.R. \& Wanless, S. 2008. Snake pipefish Entelurus aequoreus are poor food for seabirds. Ibis 150, 413-415.

Harris, M.P. \& Wanless, S. 2011. THE PUFFIN. London: T. and A. D. Poyser. Harris, M.P., Wanless, S., Murray, S. \& Mackley, E. 2004. Isle of May seabird studies in 2004. JNCC/CEH, Peterborough.

Harris M.P., Wanless, S. \& Rothery, P. 2000a. Adult survival rates of Shag Phalacrocorax aristotelis, Common Guillemot Uria aalge, Razorbill Alca torda, Puffin Fratercula arctica and Kittiwake Rissa tridactyla on the Isle of May 1986-96. Atlantic Seabirds 2, 133-150.

Harris, M.P., Wanless, S., Rothery, P., Swann, R.L. \& Jardine, D. 2000b. Survival of adult Common Guillemots Uria aalge at three Scottish colonies. Bird Study 47, 1-7. Harrison, C. 1975. NESTS, EGGS AND NESTLINGS OF BRITISH AND EUROPEAN 
BIRDS. London: Collins.

Hays, G.C., Richardson, A.J. \& Robinson, C. 2005. Climate change and marine plankton. Trends in Ecology and Evolution 20, 337-344.

Heath, M.R. 2007. Responses of fish to climate fluctuations in the Northeast Atlantic. In Practicalities of Climate Change: Adaptation and Mitigation. Proceedings of the $24^{\text {th }}$ Conference of the Institute of Ecology and Environmental Management, Cardiff, 1416 November 2006, L. Emery (ed.). IEEM, 2007, 102-116.

Heath, M.R., Rasmussen, J., Bailey, M.C., Dunn, J., Fraser, J., Gallego, A., Hay, S.J., Inglis, M. \& Robinson, S. 2012. Larval mortality rates and population dynamics of Lesser Sandeel (Ammodytes marinus) in the northwestern North Sea. Journal of Marine Systems 93, 47-57.

Heath, M.R., Speirs, D.C. \& Steele, J.H. 2014. Understanding patterns and processes in models of trophic cascades. Ecology Letters 17, 101-114.

Hedger, R., McKenzie, E., Heath, M., Wright, P., Scott, B., Gallego, A. \& Andrews, J. 2004. Analysis of the spatial distributions of mature cod (Gadus morhua) and haddock (Melanogrammus aeglefinus) abundance in the North Sea (1980-1999) using Generalised Additive Models. Fisheries Research 70, 17-25.

Hemmingsson, E. \& Eriksson, M.O.G. 2002. Ringing of Red-throated Diver Gavia stellata Black-throated Diver Gavia arctica in Sweden. Wetlands International Diver/Loon Specialist Group Newsletter 4, 8-13.

Heubeck, M. 1989. Breeding success of Shetland's seabirds: Arctic skua, kittiwake, guillemot, razorbill and puffin. In Seabirds and Sandeels: Proceedings of a seminar held in Lerwick, Shetland, 15-16 October 1988, M. Heubeck (ed.). Shetland Bird Club, 11-18.

Heubeck, M. 2009. Common Guillemot Uria aalge chick diet and breeding performance at 
Sumburgh Head, Shetland in 2007-09, compared to 1990-91. Seabird 22, 9-18.

Høines, Å., Johannesen, E. \& Bergstad, O.A. 2009. Ikke-kommersielle fiskearter - noncommercial fish. In Fisken og Havet, sarnummer 1-2009: Havets ressurser og miljф 2009, H. Gjøsæter et al. (eds.). Havforskningsinstituttet, 60-61.

Holland, G.J., Greenstreet, S.P.R., Gibb, I.M., Fraser, H.M., Robertson, M.R. 2005. Identifying sandeel Ammodytes marinus sediment habitat preferences in the marine environment. Marine Ecology Progress Series 303, 269-282.

Huntington, C.E. \& Burtt, E.H. 1972. Breeding age and longevity in Leach's Petrel (Oceanodroma leucorhoa). Proceedings of the International Ornithological Congress $15,653$.

ICES. 2004. Report of the ICES Advisory Committee on Fishery Management and Advisory Committee on Ecosystems, 2004. ICES Advice, Volume 1, Number 2. International Council for the Exploration of the Sea, Copenhagen.

ICES. 2007. Climate Change: Changing Oceans. Copenhagen: ICES. http://www.ices.dk/news-and-events/Documents/Press\%20Room/ICES\%20CLIM.pdf (accessed 30th June 2014)

ICES. 2010. Report of the Benchmark Workshop on Sandeel (WKSAN), 6-10 September 2010, Copenhagen, Denmark. ICES CM 2010/ACOM:57. 1 pp.

ICES. 2013. Report of the Herring Assessment Working Group for the Area South of $62 \mathrm{~N}$ (HAWG), 12-21 March 2013, ICES Headquarters, Copenhagen. ICES CM 2013/ACOM:06. pp.

IPCC. 2007. Climate Change 2007: The Physical Science Basis. Contribution of Working Group I to the Fourth Assessment Report of the Intergovernmental Panel on Climate Change, S. Solomon et al. (eds.). Cambridge, United Kingdom and New York, NY, USA: Cambridge University Press. 996 p. 
Jennings, S., Kaiser, M.J. \& Reynolds, J.D. 2001. MARINE FISHERIES ECOLOGY. Oxford: Blackwell.

JNCC. 2014. Seabird Population Trends and Causes of Change: 1986-2013 Report (http://www.jncc.defra.gov.uk/page-3201). Joint Nature Conservation Committee. Updated August 2014 (accessed 17th October 2014).

Johnsgard, P.A. 1987. DIVING BIRDS OF NORTH AMERICA. Lincoln: University of Nebraska Press.

Käkelä, A., Furness, R.W., Kelly, A., Strandberg, U., Waldron, S. \& Käkelä, R. 2007. Fatty acid signatures and stable isotopes as dietary indicators in North Sea seabirds. Marine Ecology Progress Series 342, 291-301.

Käkelä, R., Käkelä, A., Kahle, S., Becker, P.H., Kelly, A. \& Furness, R.W. 2005. Fatty acid signatures in plasma of captive herring gulls as indicators of demersal or pelagic fish diet. Marine Ecology Progress Series 293, 191-200.

Kirby, R.K., Johns, D.G. \& Lindley, J.A. 2006. Fathers in hot water: rising sea temperatures and a Northeastern Atlantic pipefish baby boom. Biology Letters 2, 597-600.

Klomp, N.I. \& Furness, R.W. 1991. Recruitment in long-lived birds: studies of nonbreeding great skuas. Proceedings of the International Ornithological Congress 20, 1678-1688.

Kloppmann, M.H.F. \& Ulleweit, J. 2007. Off-shelf distribution of pelagic snake pipefish, Entelurus aequoreus (Linnaeus, 1758), west of the British Isles. Marine Biology 151, $271-275$.

Kubetzki, U., Garthe, S., Fifield, D., Mendel, B. \& Furness, R.W. 2009. Individual migratory schedules and wintering areas of northern gannets. Marine Ecology Progress Series 391, 257-265.

Kvist, T., Gislason, H. \& Thyregod, P. 2001. Sources of variation in the age composition of sandeel landings. ICES Journal of Marine Science 58, 842-851. 
Lahoz-Monfort, J.J., Morgan, B.J.T., Harris, M.P., Daunt, F., Wanless, S. \& Freeman, S.N. 2013. Breeding together: modeling synchrony in productivity in a seabird community. Ecology 94, 3-10.

Lahoz-Monfort, J.J., Morgan, B.J.T., Harris, M.P., Wanless, S. \& Freeman, S.N. 2011. A capture-recapture model for exploring multi-species synchrony in survival. Methods in Ecology and Evolution 2, 116-124.

Last, J.M. 1989. The food of herring, Clupea harengus, in the North Sea, 1983-1986. Journal of Fish Biology 34, 489-501.

Lauria, V., Attrill, M.J., Brown, A., Edwards, M. \& Votier, S.C. 2013. Regional variation in the impact of climate change: evidence that bottom-up regulation from plankton to seabirds is weak in parts of the Northeast Atlantic. Marine Ecology Progress Series 488, 11-22.

Lebreton, J.-D. \& Clobert, J. 1991. Bird population dynamics, management, and conservation: the role of mathematical modelling. In Bird Population Studies: Relevance to Conservation and Management, C.M. Perrins et al. (eds.). Oxford: Oxford University Press, 105-125.

Lenoir, S., Beaugrand, G. \& Lecuyer, E. 2011. Modelled spatial distribution of marine fish and projected modifications in the North Atlantic Ocean. Global Change Biology 17, $115-129$.

Lindley, J.A., Kirby, R.R., Johns, D.G. \& Reid, P.C. 2006. Exceptional abundance of the snake pipefish (Entelurus aequoreus) in the north-eastern Atlantic Ocean. ICES CM 2006/C:06.

Lloyd, C.S. 1976. The breeding biology and survival of the Razorbill Alca torda. PhD Thesis. Oxford University, UK.

Lloyd C., Tasker M.L. \& Partridge K. 1991. THE STATUS OF SEABIRDS IN BRITAIN AND 
IRELAND. London: Poyser.

Macer, C.T. 1966. Sandeels (Ammodytidae) in the south-western North Sea: Their biology and fishery. Ministery of Agriculture, Fisheries and Food, Fishery Investigation London 24, 1-55.

Mamie, J.C.J., Beare, D.J., Jones, E.G., Kienzle, M., Dobby, H., Heath, M.R. \& Reid, D.G. 2007. Aspects of the distribution and growth of bluemouth (Helicolenus dactylopterus, Delaroche 1809) since its invasion of the northern North Sea in 1991. Fisheries Oceanography 16, 85-94.

Massey, B.W., Bradley, D.W. \& Atwood, J.L. 1992. Demography of a California least tern colony including effects of the 1982-1983 El Niño. Condor 94, 976-983.

Mavor, R.A., Parsons, M., Heubeck, M. \& Schmitt, S. 2005. Seabird numbers and breeding success in Britain and Ireland, 2004. UK Nature Conservation Report. Joint Nature Conservation Committee, Peterborough.

Mavor, R.A., Parsons, M., Heubeck, M. \& Schmitt, S. 2006. Seabird numbers and breeding success in Britain and Ireland, 2005. UK Nature Conservation Report. Joint Nature Conservation Committee, Peterborough.

Mavor, R.A., Parsons, M., Heubeck, M. \& Schmitt, S. 2007. Seabird numbers and breeding success in Britain and Ireland, 2006. UK Nature Conservation Report. Joint Nature Conservation Committee, Peterborough.

Mitchell, P.I., Newton, S.F., Ratcliffe, N. \& Dunn, T.E. 2004. SEABIRD POPULATIONS OF BRITAIN AND IRELAND. London: T. \& A.D. Poyser.

Murray, S., Harris, M.P. \& Wanless, S. In press. The Bass Rock - now the world's largest Northern Gannet colony. British Birds.

Newell, M., Harris, M.P., Burthe, S., Wanless, S. \& Daunt, F. 2013. Isle of May seabird studies in 2011 JNCC Report, No. 475g. 
Nisbet, I.C.T., Winchell, J.M. \& Heise, A.E. 1984. Influence of age on the breeding biology of Common Terns. Colonial Waterbirds 7, 117-126.

O’Brien, T.D., Li, W.K.W. \& Morán, X.A.G. (eds.). 2012. ICES Phytoplankton and Microbial Plankton Status Report 2009/2010. ICES Cooperative Research Report No. 313. $196 \mathrm{pp}$.

O’Brien, T.D., Wiebe, P.H. \& Falkenhaug, T. (eds.). 2013. ICES Zooplankton Status Report 2010/2011. ICES Cooperative Research Report No. 318. 208 pp.

O'Donald, P. 1983. THE ARCTIC SKUA: A STUDY OF THE ECOLOGY AND EVOLUTION OF A SEABIRD. Cambridge: Cambridge University Press.

OkilI, D. 1989. Breeding success of Shetland's seabirds: Red-throated Diver, Fulmar, Gannet, Cormorant and Shag. In Seabirds and Sandeels: Proceedings of a seminar held in Lerwick, Shetland, 15-16 October 1988, M. Heubeck (ed.). Shetland Bird Club, 6-11.

Okill, J.D. 1994. Ringing recoveries of red-throated divers Gavia stellata in Britain and Ireland. Ringing \& Migration 15, 107-118.

Olsson, O., Nilsson, T. \& Fransson, T. 2000. Long-Term Study of Mortality in the Common Guillemot in the Baltic Sea: Analysis of 80 Years of Ringing Data. Rapport Naturvårdsverket, 5057. Swedish Environmental Protection Agency, Stockholm.

Oro, D. \& Furness, R.W. 2002. Influences of food availability and predation on survival of kittiwakes. Ecology 83, 2516-2528.

Oswald, S.A., Bearhop, S., Furness, R.W., Huntley, B. \& Hamer, K.C. 2008. Heat stress in a high-latitude seabird: effects of temperature and food supply on bathing and nest attendance of great skuas. Journal of Avian Biology 39, 163-169.

Oswald, S.A., Huntley, B., Collingham, Y.C., Russell, D.J.F., Anderson, B.J., Arnold, J.M., Furness, R.W. \& Hamer, K.C. 2011. Physiological effects of climate on distributions of endothermic species. Journal of Biogeography 38, 430-438. 
Pace, M.L., Cole, J.J., Carpenter, S.R. \& Kitchell, J.F. 1999. Trophic cascades revealed in diverse ecosystems. Trends in Ecology \& Evolution 14, 483-488.

Payne, M.R., Hatfield, E.M.C., Dickey-Collas, M., Falkenhaug, T., Gallego, A., Gröger, J., Licandro, P., Llope, M., Munk, P., Röckmann, C., Schmidt, J.O. \& Nash, R.D.M. 2009. Recruitment in a changing environment: the 2000s North Sea herring recruitment failure. ICES Journal of Marine Science 66, 272-277.

Payne, M.R., Ross, S.D., Clausen, L.W., Munk, P., Mosegaard, H. \& Nash, R.D.M. 2013. Recruitment decline in North Sea herring is accompanied by reduced larval growth rates. Marine Ecology Progress Series 489, 197-211.

Pearson, R.G. \& Dawson, T.P. 2003. Predicting the impacts of climate change on the distribution of species: are bioclimate envelope models useful? Global Ecololgy and Biogeography 12, 361-371.

Perry, A.L., Low, P.J., Ellis, J.R. \& Reynolds, J.D. 2005. Climate change and distribution shifts in marine fishes. Science 308, 1912-1915.

Pinaud, D. \& Weimerskirch, H. 2002. Ultimate and proximate factors affecting the breeding performance of a marine top-predator. Oikos 99, 141-150.

Pitois, S.G., Lynam, C.P., Jansen, T., Halliday, N. \& Edwards, M. 2012. Bottom-up effects of climate on fish populations: data from the Continuous Plankton Recorder. Marine Ecology Progress Series 456, 169-186.

Polis, G.A., Sears, A.L.W., Huxel, G.R., Strong, D.R. \& Maron, J. 2000. When is a trophic cascade a trophic cascade? Trends in Ecology \& Evolution 15, 473-475.

Potts, G.R., Coulson, J.C. \& Deans, I.R. 1980. Population dynamics and breeding success of the Shag, Phalacrooorax aristotelis, on the Farne Islands, Northumberland. Journal of Animal Ecology 49,465-484.

Poulard, J.-C. \& Blanchard, F. 2005. The impact of climate change on the fish community 
structure of the eastern continental shelf of the Bay of Biscay. ICES Journal of Marine Science 62, 1463-1443.

Prévot-Julliard, A.-C., Lebreton, J.-D. \& Pradel, R. 1998. Re-Evaluation of Adult Survival of Black-Headed Gulls (Larus ridibundus) in Presence of Recapture Heterogeneity. The Auk 115, 85-95.

Proctor, R., Wright, P.J. \& Everitt, A. 1998. Modelling the transport of larval sandeels on the north west European shelf. Fisheries Oceanography 7, 347-354.

Ratcliffe, N., Catry, P., Hamer, K.C., Klomp, N.I. \& Furness, R.W. 2002. The effect of age and year on the survival of breeding adult great skuas Catharacta skua in Shetland. Ibis 144, 384-392.

Ratcliffe, N., Newton, S., Morrison, P., Merne, O., Cadwallender, T. \& Frederiksen, M. 2008. Adult Survival and Breeding Dispersal of Roseate Terns Within the Northwest European Metapopulation. Waterbirds 31, 320-329.

Reed, T.E., Wanless, S., Harris, M.P., Frederiksen, M., Kruuk, L.E.B. \& Cunningham, E.J.A. 2006. Responding to environmental change: plastic responses vary little in a synchronous breeder. Proceedings of the Royal Society of London B - Biological Sciences 273, 2713-2719.

Reeves, S.A. 1994. Seasonal and annual variation in catchability of sandeels at Shetland. ICES CM. D:19.

Reid, P.C., de Fatima Borges, M. \& Svendsen, E. 2001. A regime shift in the North Sea circa 1988 linked to changes in the North Sea horse mackerel fishery. Fisheries Research 50, $163-171$.

Reid, P.C., Edwards, M., Hunt, H.G. \& Warner, A.J. 1998. Phytoplankton change in the North Atlantic. Nature 391, 546.

Reygondeau, G. \& Beaugrand, G. 2011. Future climate-driven shifts in distribution of 
Calanus finmarchicus. Global Change Biology 17, 756-766.

Reynolds, T.J., Harris, M.P., King, R., Swann, R.L., Jardine, D.C., Frederiksen, M. \& Wanless, S. 2011. Among-colony synchrony in the survival of Common Guillemots Uria aalge reflects shared wintering areas. Ibis 153, 818-831.

Richardson, A.J. \& Schoeman, D.S. 2004. Climate impacts on plankton ecosystems in the Northeast Atlantic. Science 305, 1609-1612.

Rindorf, A., Wanless, S. \& Harris, M.P. 2000. Effects of sandeel availability on the reproductive output of seabirds. Marine Ecology Progress Series 202, 241-252.

Robinson, R.A. 2005. BirdFacts: profiles of birds occurring in Britain \& Ireland (BTO Research Report 407). BTO, Thetford. Online. http://www.bto.org/birdfacts. (accessed 28th October 2014).

Robinson, R.A. 2010. Estimating age-specific survival rates from historical ringing data. Ibis 152, 651-653.

Russell, D.J.F., Wanless, S., Collingham, Y.C., Anderson, B.J., Beale, C., Reid, J.B., Huntley, B. \& Hamer, K.C. 2014. Beyond climate envelopes: bio-climate modelling accords with observed 25-year changes in seabird populations of the British Isles. Diversity and Distributions, DOI: 10.1111/ddi.12272.

Sæther, B.-E. \& Bakke, Ø. 2000. Avian life history variation and contribution of demographic traits to the population growth rate. Ecology 81, 642-653.

Sætre, R., Toresen, R., Søiland, H. \& Fossum, P. 2002. The Norwegian spring-spawning herring-spawning, larval drift and larval retention. Sarsia 87, 167-178.

Sandvik, H., Erikstad, K.E., Barrett, R.T. \& Yoccoz, N.G. 2005. The effect of climate on adult survival in five species of North Atlantic seabirds. Journal of Animal Ecology 74, 817-831.

Schwartzlose, R.A., Alheit, J., Bakun, A., Baumgartner, T.R., Cloete, R., Crawford, R.J.M., 
Fletcher, W.J., Green-Ruiz, Y., Hagen, E., Kawasaki, T., Lluch-Belda, D., LluchCota, S.E., MacCall, A.D., Matsuura, Y., Nevárez-Martínez, M.O., Parrish, R.H., Roy, C., Serra, R., Shust, K.V., Ward, M.N. \& Zuzunaga, J.Z. 1999. Worldwide large-scale fluctuations of sardine and anchovy populations. South African Journal of Marine Science 21, 289-347.

Scott, B.E., Sharples, J., Wanless, S., Ross, O., Frederiksen, M. \& Daunt, F. 2006. The use of biologically meaningful oceanographic indices to separate the effects of climate and fisheries on seabird breeding success. In Top predators in marine ecosystems: their role in monitoring and management, I. Boyd et al. (eds.). Cambridge: Cambridge University Press, 46-62.

Scott, D.A. 1970. The breeding biology of the Storm Petrel. $\mathrm{PhD}$ thesis, University of Oxford, UK.

Simpson, S.D., Jennings, S., Johnson, M.P., Blanchard, J., Schön, P.-J., Sims, D.W. \& Genner, M.J. 2011. Continental Shelf-Wide Response of a Fish Assemblage to Rapid Warming of the Sea. Current Biology 21, 1565-1570.

Smout, S., Rindorf, A., Wanless, S., Daunt, F., Harris, M.P. \& Matthiopoulos, J. 2013. Seabirds maintain offspring provisioning rate despite fluctuations in prey abundance: a multi-species functional response for guillemots in the North Sea. Journal of Applied Ecology 50, 1071-1079.

Snow, D.W. \& Perrins, C.M. 1998. THE BIRDS OF THE WESTERN PALEARCTIC. Oxford: Oxford University Press, Concise edition.

Spendelow, J.A. 1991. Postfledging Survival and Recruitment of Known-Origin Roseate Terns (Sterna dougallii) at Falkner Island, Connecticut. Colonial Waterbirds 14, 108115.

Tavecchia, G., Baccetti, N. \& Serra, L. 2006. Modelling survival and movement probability 
of Little Tern Sterna albifrons at a post- breeding moulting site: the effect of the colony of origin. In Waterbirds around the world, G.C. Boere et al. (eds.). Edinburgh: The Stationery Office, 560-561.

Thaxter, C., Lascelles, B., Sugar, K., Cook, A.S., Roos, S., Bolton, M., Langston, R. \& Burton, N.H., 2012. Seabird foraging ranges as a preliminary tool for identifying candidate Marine Protected Areas. Biological Conservation 156, 53-61.

Thompson, K.R. 1987. The ecology of the Manx shearwater Puffinus Puffinus on Rhum, West Scotland. PhD thesis, University of Glasgow, UK.

van Damme, C.J.G. \& Couperus, A.S. 2008. Mass occurrence of snake pipefish: result of a change in climate? Journal of Sea Research 60, 117-125.

van Deurs M., Hal, R.V., Tomczak, M.T., Jónasdóttir, S.H. \& Dolmer, P. 2009. Recruitment of Lesser Sandeel Ammodytes marinus in relation to density dependence and zooplankton composition. Marine Ecology Progress Series 381, 249-258.

van Deurs M., Hartvig, M. \& Steffensen, J.F. 2011. Critical threshold size for overwintering sandeels (Ammodytes marinus). Marine Biology 158, 2755-2764.

Van Deurs M., Koski, M. \& Rindorf, A. 2014. Does copepod size determine food consumption of particulate feeding fish? ICES Journal of Marine Science 71, 35-43.

Votier, S.C., Bearhop, S., Crane, J.E., Arcos, J.M. \& Furness, R.W. 2007. Seabird predation by great skuas Stercorarius skua - intra-specific competition for food? Journal of Avian Biology 38, 234-246.

Votier, S.C., Furness, R.W., Bearhop, S., Crane, J.E., Caldow, R.W.G., Catry, P., Ensor, K., Hamer, K.C., Hudson, A.V., Kalmbach, E., Klomp, N.I., Pfeiffer, S., Phillips, R.A., Prieto, I. \& Thompson, D.R. 2004. Changes in fisheries discard rates and seabird communities. Nature 427, 727-730. 
Votier, S.C., Hatchwell, B.J., Beckerman, A., McCleery, R.H., Hunter, F.M., Trinder, M. \& Birkhead, T.R. 2005. Oil pollution and climate have wide-scale impacts on seabird demographics. Ecology Letters 8, 1157-1164.

Wanless, S., Frederiksen, M., Harris, M.P. \& Freeman, S.N. 2006. Survival of Gannets Morus bassanus in Britain and Ireland, 1959-2002. Bird Study 53, 79-85.

Wanless, S. \& Harris, M.P. 2012. Scottish seabirds - past, present \& future. Scottish Birds 32, $38-45$.

Wanless, S., Harris, M.P., Calladine, J. \& Rothery, P. 1996. Modelling Responses of Herring Gull and Lesser Black Backed Gull Populations to Reduction of Reproductive Output: Implications for Control Measures. Journal of Applied Ecology 33, 1420-1432.

Wanless, S., Harris, M.P. \& Greenstreet, S.P.R. 1998. Summer sandeel consumption by seabirds breeding in the Firth of Forth, south-east Scotland. ICES Journal of Marine Science 55, 1141-1151.

Wanless, S., Harris, M.P., Redman, P. \& Speakman, J. 2005b. Low energy values of fish as a probable cause of a major seabird breeding failure in the North Sea. Marine Ecology Progress Series 294, 1-8.

Wanless, S., Murray, S. \& Harris, M.P. 2005a. The status of Northern Gannet in Britain \& Ireland in 2003 / 04. British Birds 98, 280-294.

Wanless, S., Wright, P.J., Harris, M.P. \& Elston, D.A. 2004. Evidence for decrease in size of lesser sandeels Ammodytes marinus in a North Sea aggregation over a 30-yr period. Marine Ecology Progress Series 279, 237-246.

Wilson, L.J., Daunt, F. \& Wanless, S. 2004. Self-feeding and chick-provisioning diet differ in the Common Guillemot Uria aalge. Ardea 92, 197-208. 
Winslade, P. 1974. Behavioural studies on the lesser sandeel Ammodytes marinus (Raitt) III. The effect of temperature on activity and the environmental control of the annual cycle of activity. Journal of Fish Biology 6, 587-599.

Wright, P. \& Bailey, M.C. 1993. Biology of Sandeels in the Vicinity of Seabird Colonies at Shetland. Fisheries Research Services Report, 15/93. Marine Laboratory, Aberdeen. $64 \mathrm{pp}$.

Wright, P.J. \& Bailey, M.C. 1996. Timing of hatching in Ammodytes marinus from Shetland waters and its significance to early growth and survivorship. Marine Biology 126, $143-152$.

Wright, P.J., Jensen, H. \& Tuck, I. 2000. The influence of sediment type on the distribution of the lesser sandeel, Ammodytes marinus. Journal of Sea Research 44, 243-256. 


\section{TABLE 1}

Table 1. Names and life history characteristics of seabird species regularly breeding in the British Isles, which are included in the JNCC's Seabird Monitoring Programme, and the Seabird Colony Register. All except the Red-throated diver were included in the Seabird 2000 census or Seabird Colony Register. Source: JNCC, http://www.jncc.gov.uk/page-3201 General diet description taken from (Robinson 2005). Data on seabird clutch size is taken from Snow \& Perrins (1998) and Harrison (1975) unless stated otherwise. Lifespan is calculated as $\lambda=\mu-1 / \ln (\varphi)$, where $\lambda=$ lifespan, $\mu=$ age at first breeding $\& \varphi=$ adult survival rate (Robinson 2005). 


\begin{tabular}{|c|c|c|c|c|c|c|}
\hline $\begin{array}{l}\text { Common } \\
\text { name }\end{array}$ & $\begin{array}{l}\text { Scientific } \\
\text { name }\end{array}$ & General Diet & $\begin{array}{l}\text { Clutch size } \\
\text { (no. eggs) }\end{array}$ & $\begin{array}{l}\text { Age at } \\
\text { first } \\
\text { breeding } \\
\text { (years) }\end{array}$ & $\begin{array}{l}\text { Adult } \\
\text { survival } \\
\text { rate } \\
\left(\text { year }^{-1}\right)\end{array}$ & $\begin{array}{l}\text { Lifespa } \\
\mathrm{n} \\
\text { (years) }\end{array}$ \\
\hline $\begin{array}{l}\text { Red-throated } \\
\text { diver* }\end{array}$ & $\begin{array}{l}\text { Gavia stellata } \\
*\end{array}$ & $\begin{array}{l}\text { Primarily fish, } \\
\text { captured by } \\
\text { seizing in bill, } \\
\text { also frogs, } \\
\text { large } \\
\text { invertebrates. }\end{array}$ & 2 & $\begin{array}{l}3 \text { (Okill } \\
1994)\end{array}$ & $\begin{array}{l}0.840 \\
\text { (Hemmi } \\
\text { ngsson } \\
\& \\
\text { Eriksso } \\
\text { n 2002) }\end{array}$ & 9 \\
\hline $\begin{array}{l}\text { Northern } \\
\text { Fulmar }\end{array}$ & $\begin{array}{l}\text { Fulmarus } \\
\text { glacialis }\end{array}$ & $\begin{array}{l}\text { Crustaceans, } \\
\text { squid, fish, } \\
\text { offal, carrion } \\
\text { mostly from } \\
\text { surface. }\end{array}$ & 1 & $\begin{array}{l}9 \\
\text { (Dunnet } \\
\& \\
\text { Ollason } \\
\text { 1978a) }\end{array}$ & $\begin{array}{l}0.972 \\
\text { (Dunnet } \\
\& \\
\text { Ollason } \\
1978 b \text { ) }\end{array}$ & 44 \\
\hline $\begin{array}{l}\text { Manx } \\
\text { Shearwater }\end{array}$ & $\begin{array}{l}\text { Puffinus } \\
\text { puffinus }\end{array}$ & $\begin{array}{l}\text { Mostly small } \\
\text { fish and squid, } \\
\text { also small } \\
\text { crustaceans } \\
\text { and offal from } \\
\text { surface or } \\
\text { diving. }\end{array}$ & 1 & $\begin{array}{l}5 \\
\text { (Thomp } \\
\text { son } \\
\text { 1987) }\end{array}$ & $\begin{array}{l}0.905 \\
\text { (Brooke } \\
1990)\end{array}$ & 15 \\
\hline $\begin{array}{l}\text { European } \\
\text { Storm-petrel }\end{array}$ & $\begin{array}{l}\text { Hydrobates } \\
\text { pelagicus }\end{array}$ & $\begin{array}{l}\text { Mainly surface } \\
\text { plankton, } \\
\text { small fish, }\end{array}$ & 1 & $\begin{array}{l}4-5 \\
(\text { Scott } \\
1970)\end{array}$ & $\begin{array}{l}0.870 \\
\text { (Cramp } \\
\text { et al. }\end{array}$ & $11-12$ \\
\hline
\end{tabular}




\begin{tabular}{|c|c|c|c|c|c|c|}
\hline & & $\begin{array}{l}\text { feeds from } \\
\text { water surface } \\
\text { without } \\
\text { alighting. }\end{array}$ & & & $\begin{array}{l}\text { 1977- } \\
94)\end{array}$ & \\
\hline $\begin{array}{l}\text { Leach's } \\
\underline{\text { Storm-petrel }}\end{array}$ & $\begin{array}{l}\text { Oceanodroma } \\
\text { leucorhoa }\end{array}$ & $\begin{array}{l}\text { Mainly surface } \\
\text { plankton, } \\
\text { small fish, } \\
\text { feeds from } \\
\text { water surface } \\
\text { without } \\
\text { alighting. }\end{array}$ & 1 & $\begin{array}{l}\text { 4-5 } \\
\text { (Huntin } \\
\text { gton \& } \\
\text { Burtt } \\
1972 \text { ) }\end{array}$ & $\begin{array}{l}0.880 \\
\text { (Furness } \\
1984)\end{array}$ & $12-13$ \\
\hline $\begin{array}{l}\text { Northern } \\
\text { Gannet }\end{array}$ & $\begin{array}{l}\text { Morus } \\
\text { bassanus }\end{array}$ & $\begin{array}{l}\text { Fish (up to } \\
30 \mathrm{~cm} \text { ), usually } \\
\text { plunging from } \\
\text { heights of } 10- \\
40 \mathrm{~m} \text {. }\end{array}$ & 1 & $\begin{array}{l}5 \\
\text { (Alersta } \\
\text { m 1990) }\end{array}$ & $\begin{array}{l}0.919 \\
\text { (Wanles } \\
\text { s et al. } \\
\text { 2006) }\end{array}$ & 17 \\
\hline $\begin{array}{l}\text { Great } \\
\text { Cormorant }\end{array}$ & $\begin{array}{l}\text { Phalacrocora } \\
x \text { carbo }\end{array}$ & $\begin{array}{l}\text { Fish, mostly } \\
\text { by diving from } \\
\text { surface. }\end{array}$ & $3-4$ & $\begin{array}{l}2-4 \\
\text { (Cramp } \\
1977)\end{array}$ & $\begin{array}{l}0.880 \\
\text { (Frederi } \\
\text { ksen \& }\end{array}$ & $10-12$ \\
\hline
\end{tabular}




\begin{tabular}{|c|c|c|c|c|c|c|}
\hline & & & & & $\begin{array}{l}\text { Bregnba } \\
\text { lle } \\
\text { 2000) }\end{array}$ & \\
\hline $\begin{array}{l}\text { European } \\
\text { Shag }\end{array}$ & $\begin{array}{l}\text { Phalacrocora } \\
x \text { aristotelis }\end{array}$ & $\begin{array}{l}\text { Fish, mostly } \\
\text { by diving from } \\
\text { surface. }\end{array}$ & 3 & $\begin{array}{l}3 \text { (Potts } \\
\text { et al. } \\
1980)\end{array}$ & $\begin{array}{l}0.878 \\
\text { (Harris } \\
\text { et al. } \\
1994)\end{array}$ & 11 \\
\hline Arctic Skua & $\begin{array}{l}\text { Stercorarius } \\
\text { parasiticus }\end{array}$ & $\begin{array}{l}\text { Summer: } \\
\text { mostly birds, } \\
\text { small } \\
\text { mammals, } \\
\text { insects; } \\
\text { Winter: fish, } \\
\text { mostly by } \\
\text { piracy from } \\
\text { other birds. }\end{array}$ & $\begin{array}{l}2 \text { (Furness } \\
1987)\end{array}$ & $\begin{array}{l}4 \text { (Lloyd } \\
\text { et al. } \\
1991)\end{array}$ & $\begin{array}{l}0.886 \\
\text { (O'Dona } \\
\text { ld 1983) }\end{array}$ & 12 \\
\hline Great Skua & $\begin{array}{l}\text { Catharacta } \\
\text { skua }\end{array}$ & $\begin{array}{l}\text { Mostly fish, } \\
\text { obtained from } \\
\text { sea, } \\
\text { scavenging or } \\
\text { by piracy. }\end{array}$ & $\begin{array}{l}2 \text { (Furness } \\
1987)\end{array}$ & $\begin{array}{l}7 \\
\text { (Klomp } \\
\& \\
\text { Furness } \\
1991)\end{array}$ & $\begin{array}{l}0.888 \\
\text { (Ratcliff } \\
\text { e et al. } \\
\text { 2002) }\end{array}$ & 15 \\
\hline $\begin{array}{l}\text { Mediterranean } \\
\text { Gull }\end{array}$ & $\begin{array}{l}\text { Larus } \\
\text { melanocephal } \\
\text { us }\end{array}$ & $\begin{array}{l}\text { Summer: } \\
\text { insects; } \\
\text { Winter: marine }\end{array}$ & 3 & $N A$ & $N A$ & $N A$ \\
\hline
\end{tabular}




\begin{tabular}{|c|c|c|c|c|c|c|}
\hline & & $\begin{array}{l}\text { fish and } \\
\text { molluscs. }\end{array}$ & & & & \\
\hline $\begin{array}{l}\text { Black-headed } \\
\text { Gull }\end{array}$ & $\begin{array}{l}\text { Larus } \\
\text { ridibundus }\end{array}$ & $\begin{array}{l}\text { Opportunist, } \\
\text { insects, } \\
\text { earthworms, } \\
\text { also plant } \\
\text { material and } \\
\text { scraps. }\end{array}$ & $2-3$ & $\begin{array}{l}2-5 \\
\text { (Clobert } \\
\text { et al. } \\
1994)\end{array}$ & $\begin{array}{l}0.900 \\
\text { (Prévot- } \\
\text { Julliard } \\
\text { et al. } \\
\text { 1998) }\end{array}$ & $11-14$ \\
\hline$\underline{\text { Mew Gull }}$ & Larus canus & $\begin{array}{l}\text { Invertebrates, } \\
\text { some fish, } \\
\text { preference for } \\
\text { foraging on } \\
\text { ground. }\end{array}$ & 3 & $\begin{array}{l}\text { 3-4 } \\
\text { (Cramp } \\
\& \\
\text { Simmon } \\
\text { s 1983) }\end{array}$ & $\begin{array}{l}0.860 \\
\text { (Buckci } \\
\text { cinski \& } \\
\text { Buckcic } \\
\text { inska } \\
\text { 2003) }\end{array}$ & $10-11$ \\
\hline $\begin{array}{l}\text { Lesser Black- } \\
\underline{\text { backed Gull }}\end{array}$ & Larus fuscus & $\begin{array}{l}\text { Omnivorous, } \\
\text { often feeds at } \\
\text { rubbish dumps }\end{array}$ & 3 & $\begin{array}{l}4-5 \\
(\text { Harris } \\
1970)\end{array}$ & $\begin{array}{l}0.913 \\
\text { (Wanles } \\
\text { s et al. }\end{array}$ & $15-16$ \\
\hline
\end{tabular}




\begin{tabular}{|c|c|c|c|c|c|c|}
\hline & & $\begin{array}{l}\text { or on shoals of } \\
\text { fish. }\end{array}$ & & & 1996) & \\
\hline Herring Gull & $\begin{array}{l}\text { Larus } \\
\text { argentatus }\end{array}$ & $\begin{array}{l}\text { Omnivorous, } \\
\text { but mostly } \\
\text { animal } \\
\text { material, also } \\
\text { scavenges and } \\
\text { pirates food. }\end{array}$ & 3 & $\begin{array}{l}4-5 \\
(\text { Chabrz } \\
\text { yk \& } \\
\text { Coulson } \\
1976)\end{array}$ & $\begin{array}{l}0.880 \\
\text { (Wanles } \\
\text { s et al. } \\
1996 \text { ) }\end{array}$ & $12-13$ \\
\hline $\begin{array}{l}\text { Great Black- } \\
\text { backed Gull }\end{array}$ & \begin{tabular}{|l} 
Larus \\
marinus
\end{tabular} & $\begin{array}{l}\text { Omnivorous, } \\
\text { but mostly } \\
\text { animals } \\
\text { including other } \\
\text { seabirds, also } \\
\text { scavenges and } \\
\text { pirates food. }\end{array}$ & $2-3$ & $\begin{array}{l}4-5 \\
\text { (Cramp } \\
\& \\
\text { Simmon } \\
\text { s 1983) }\end{array}$ & $N A$ & $N A$ \\
\hline $\begin{array}{l}\text { Black-legged } \\
\text { Kittiwake }\end{array}$ & $\begin{array}{l}\text { Rissa } \\
\text { tridactyla }\end{array}$ & $\begin{array}{l}\text { Mainly marine } \\
\text { invertebrates } \\
\text { and fish. }\end{array}$ & 2 & $\begin{array}{l}3-4 \\
\text { (Coulso } \\
\text { n \& } \\
\text { White } \\
1959)\end{array}$ & $\begin{array}{l}0.882 \\
\text { (Harris } \\
\text { et al. } \\
\text { 2000a) }\end{array}$ & $11-12$ \\
\hline $\begin{array}{l}\text { Sandwich } \\
\text { Tern }\end{array}$ & $\begin{array}{l}\text { Sterna } \\
\text { sandvicensis }\end{array}$ & $\begin{array}{l}\text { Fish, mostly } \\
\text { plunge-diving. }\end{array}$ & $1-2$ & $\begin{array}{l}3 \text { (Snow } \\
\& \\
\text { Perrins } \\
1998 \text { ) }\end{array}$ & $\begin{array}{l}0.898( \\
\text { Robinso } \\
\text { n 2010) }\end{array}$ & 12 \\
\hline Roseate Tern & Sterna & Fish, mostly & $1-2$ & $3-4$ & 0.855( & $9-10$ \\
\hline
\end{tabular}




\begin{tabular}{|c|c|c|c|c|c|c|}
\hline & dougallii & plunge-diving. & & $\begin{array}{l}\text { (Spendel } \\
\text { ow } \\
\text { 1991) }\end{array}$ & $\begin{array}{l}\text { Ratcliff } \\
\text { e et al. } \\
\text { 2008) }\end{array}$ & \\
\hline $\begin{array}{l}\text { Common } \\
\text { Tern }\end{array}$ & $\begin{array}{l}\text { Sterna } \\
\text { hirundo }\end{array}$ & $\begin{array}{l}\text { Mostly fish, } \\
\text { also } \\
\text { crustaceans in } \\
\text { some areas, } \\
\text { mostly by } \\
\text { plunge-diving. }\end{array}$ & $2-3$ & $\begin{array}{l}3-4 \\
\text { (Nisbet } \\
\text { et al. } \\
1984 \text { ) }\end{array}$ & $\begin{array}{l}0.900 \text { ( } \\
\text { Becker } \\
\& \\
\text { Ludwig } \\
\text { s 2004) }\end{array}$ & $12-13$ \\
\hline Arctic Tern & $\begin{array}{l}\text { Sterna } \\
\text { paradisaea }\end{array}$ & $\begin{array}{l}\text { Fish, } \\
\text { crustaceans } \\
\text { and insects. }\end{array}$ & $1-2$ & $\begin{array}{l}4 \\
\text { (Coulso } \\
\text { n \& } \\
\text { Horobin } \\
1976)\end{array}$ & $\begin{array}{l}0.900 \text { ( } \\
\text { Balmer } \\
\text { \& Peach } \\
1997 \text { ) }\end{array}$ & 13 \\
\hline Little Tern & $\begin{array}{l}\text { Sterna } \\
\text { albifrons }\end{array}$ & $\begin{array}{l}\text { Small fish and } \\
\text { invertebrates, } \\
\text { often hovers } \\
\text { before plunge- } \\
\text { diving. }\end{array}$ & $2-3$ & $\begin{array}{l}3 \\
\text { (Massey } \\
\text { et al } \\
1992 \text { ) }\end{array}$ & $\begin{array}{l}0.899 \text { ( } \\
\text { Tavecch } \\
\text { ia et al. } \\
\text { 2006) }\end{array}$ & 12 \\
\hline $\begin{array}{l}\text { Common } \\
\text { emot }\end{array}$ & Uria aalge & $\begin{array}{l}\text { Mostly fish, } \\
\text { usually taken } \\
\text { from depths up }\end{array}$ & 1 & $\begin{array}{l}5 \\
\text { (Olsson } \\
\text { et al. }\end{array}$ & $\begin{array}{l}0.946 \text { ( } \\
\text { Harris } \\
\text { et al. }\end{array}$ & 23 \\
\hline
\end{tabular}




\begin{tabular}{|c|c|c|c|c|c|c|}
\hline & & to $60 \mathrm{~m}$. & & 2000) & 2000b) & \\
\hline Razorbill & Alca torda & $\begin{array}{l}\text { Fish, some } \\
\text { invertebrates. }\end{array}$ & 1 & $\begin{array}{l}4-5 \\
\text { (Lloyd } \\
1976)\end{array}$ & $\begin{array}{l}0.900 \text { ( } \\
\text { Chapdel } \\
\text { aine } \\
\text { 1997) }\end{array}$ & 13-14 \\
\hline $\begin{array}{l}\underline{\text { Black }} \\
\text { Guillemot }\end{array}$ & $\begin{array}{l}\text { Cepphus } \\
\text { grille }\end{array}$ & $\begin{array}{l}\text { Mostly fish, } \\
\text { also } \\
\text { crustaceans } \\
\text { especially in } \\
\text { the Arctic. }\end{array}$ & $1-2$ & $\begin{array}{l}3-4 \\
\text { (Ewins } \\
1988)\end{array}$ & $\begin{array}{l}0.870( \\
\text { Frederik } \\
\text { sen \& } \\
\text { Petersen } \\
\text { 1999) }\end{array}$ & $10-11$ \\
\hline $\begin{array}{l}\text { Atlantic } \\
\underline{\text { Puffin }}\end{array}$ & $\begin{array}{l}\text { Fratercula } \\
\text { arctica }\end{array}$ & $\begin{array}{l}\text { Mostly fish, } \\
\text { also } \\
\text { crustaceans } \\
\text { especially in } \\
\text { the Arctic. }\end{array}$ & 1 & $\begin{array}{l}\text { 4-6 } \\
\text { (Harris } \\
\text { 1983, } \\
\text { Johnsgar } \\
\text { d 1987) }\end{array}$ & $\begin{array}{l}0.924 \\
\text { (Harris } \\
\text { et al. } \\
1997)\end{array}$ & $17-19$ \\
\hline
\end{tabular}




\section{FIGURE 1}

Changes in the numbers of breeding seabirds in the United Kingdom 1969-2002 (JNCC 2014). Percentage changes refer to coastal-nesting seabirds only -inland colonies were not surveyed during the Operation Seafarer (1969-70) (Cramp et al. 1974) and the Seabird Colony Register Census (SCR) (1985-88)(Lloyd et al. 1991). Manx Shearwater, Leach's Storm petrel and European Storm-petrel are omitted as they were not surveyed during the Operation Seafarer (1969-70) and the SCR Census (1985-88). Survey methods for Black Guillemots during Operation Seafarer (1969-70) were not comparable with Seabird 2000 (1998-2002). Change from 2000-2012 (i.e. over the period since the last national census) is estimated from trends derived from the Seabirds Monitoring Programme sample of colonies; this analysis is only available for species with sufficient data to accurately estimate trends. *change between censuses in 1984-5 and 2004-5.

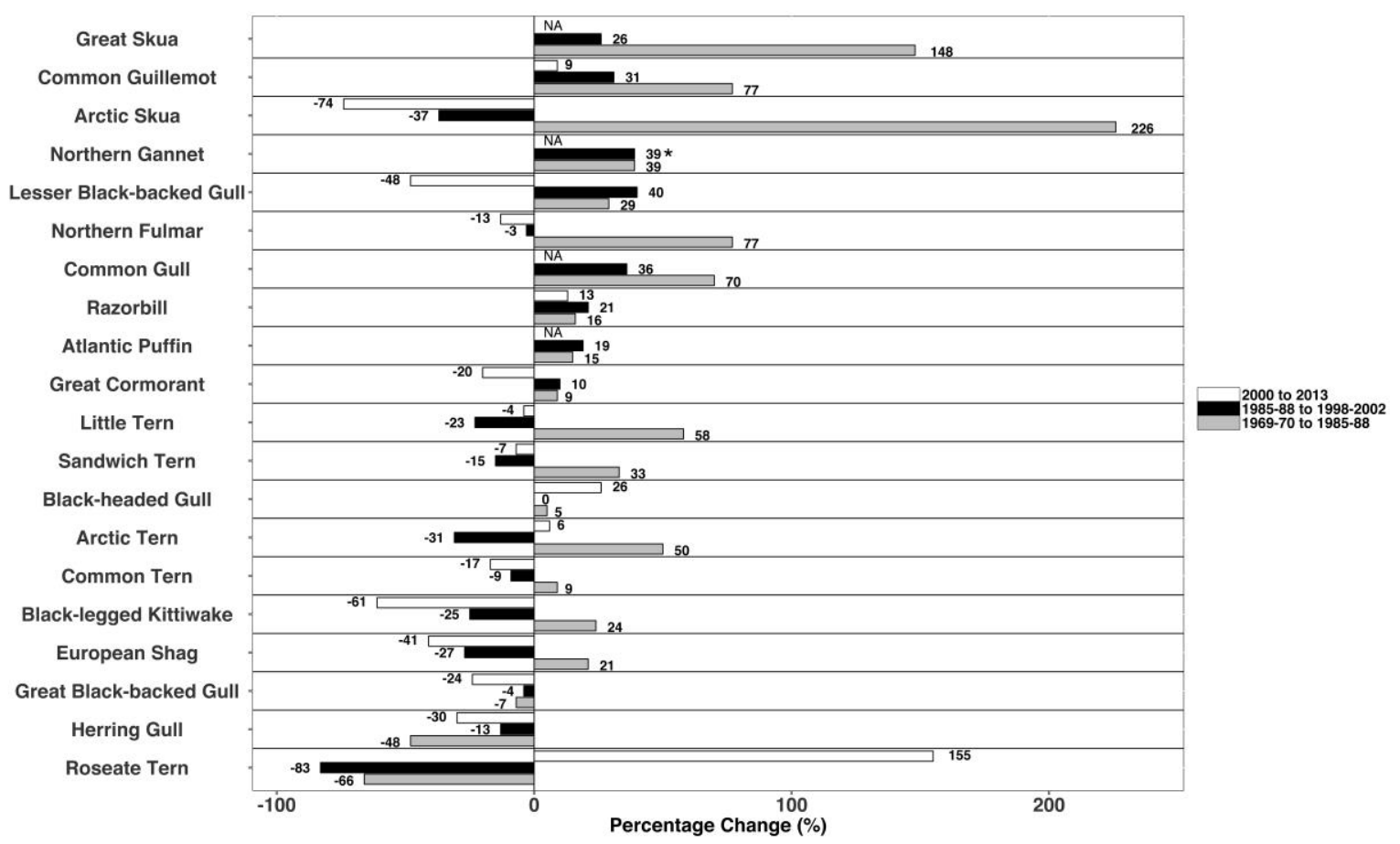




\section{FIGURE 2}

Changes in the numbers of breeding seabirds in Scotland, England and Wales during the period 2000-2013 (JNCC 2014). Change from 2000-2013 (i.e. over the period since the last national census) is estimated from trends derived from the Seabirds Monitoring Programme sample of colonies; this analysis is only available for species with sufficient data to accurately estimate trends (JNCC 2014).

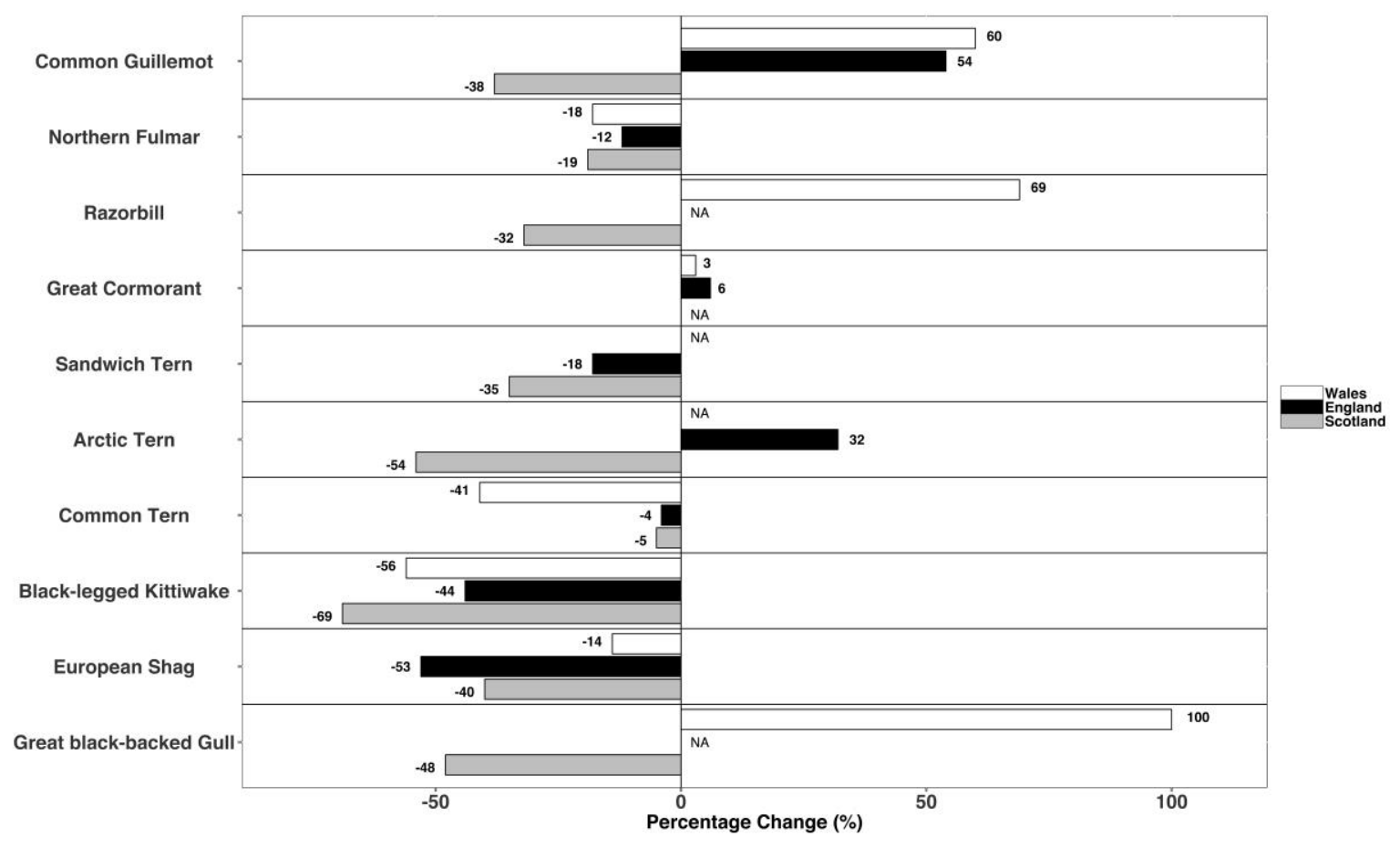




\section{FIGURE 3}

From Friederikson et al. (2007). Simplified diagram of some documented and probable trophic and climatic controls in the North Sea pelagic ecosystem. 1: bottom-up control of zooplankton by phytoplankton (Richardson \& Schoeman 2004); 2: bottom-up control of sandeel larvae by zooplankton (Frederiksen et al. 2006); 3: bottom-up control of seabird breeding success by sandeels (Hamer et al. 1993, Frederiksen et al. 2006); 4: top-down control of zooplankton by herring predation (Arrhenius 1997); 5: bottom-up control of herring by zooplankton (Corten 2001, Beaugrand 2004); 6: top-down control of sandeels by herring predation (Friederikson et al. 2007); 7: top-down control of herring by human fisheries (Jennings et al. 2001); 8: local top-down control of sandeels by human fisheries (Rindorf et al. 2000); 9: climatic control of herring recruitment (Sætre et al. 2002); 10 and 11: climatic control of phytoplankton and zooplankton (Edwards \& Richardson 2004, Hays et al. 2005); 12: climatic control of sandeel recruitment (not known if direct) (Arnott \& Ruxton 2002).

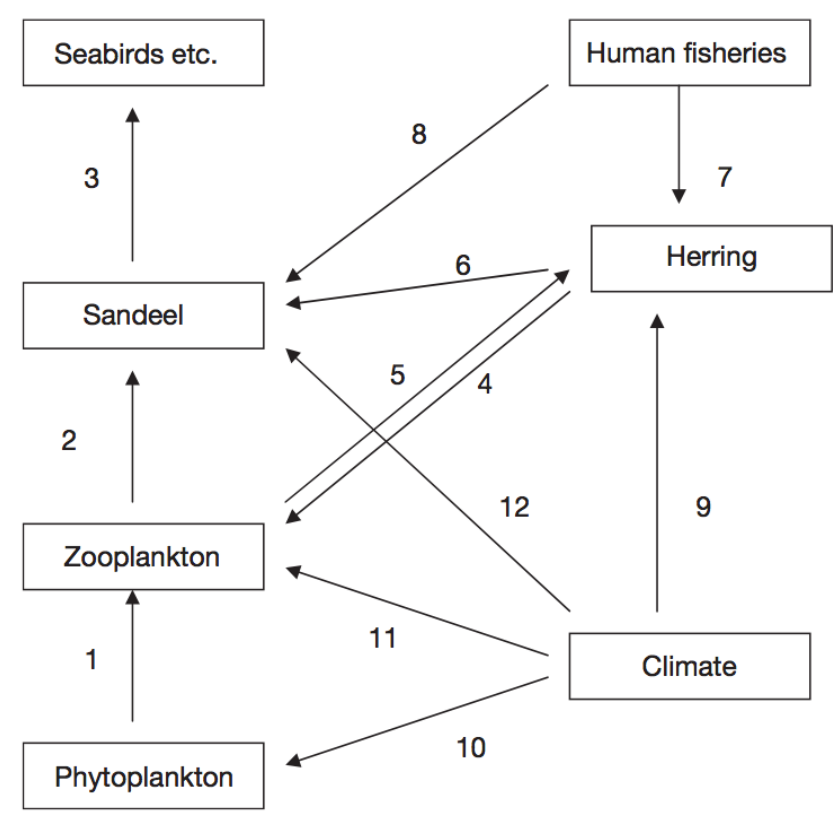




\section{FIGURE 4}

Catch per unit effort of sandeel larvae off the Firth of Forth (bars) and abundance of early larvae (3-7 days old) at Stonehaven (symbols and lines). CPUE data from 1990 to 2000 was derived from analysis of vessel log-books from the Danish sandeel fishery. CPUE Data from 2000 onwards is taken from a supervised monitoring fishery. CPUE data for 2006 and 2007 is taken from H. Jensen, Danish Institute for Fisheries Research. Larval abundance was measured at Stonehaven (between $56^{\circ} 57.83 \mathrm{~N}$ and $002^{\circ} 06.74 \mathrm{~W}$ ) and is taken from Heath et al. (2012). The dotted line delineates the fishery closure.

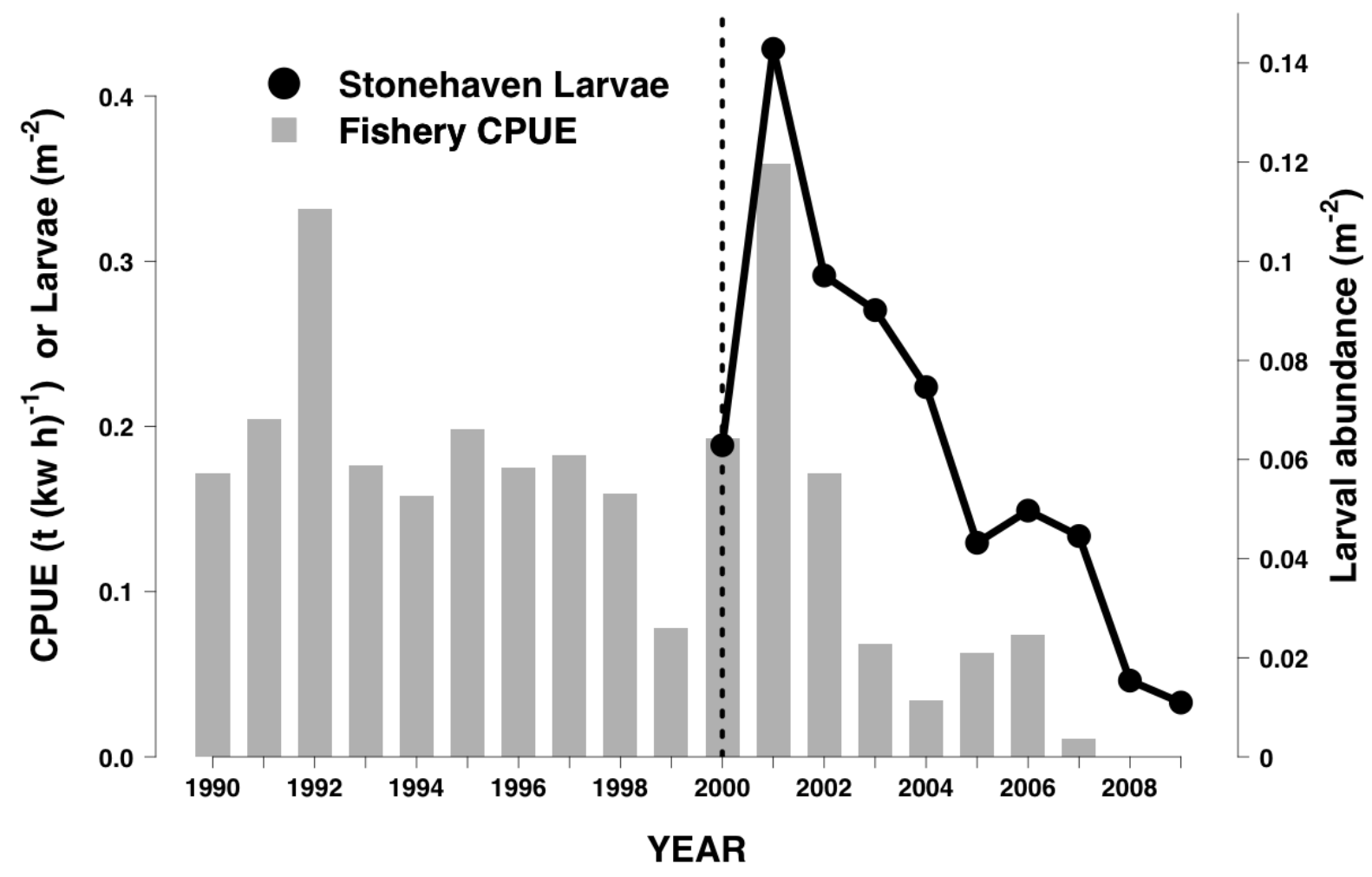




\section{FIGURE 5}

4-year aggregated mean $(\log 10)$ abundance of snake pipefish caught by commercial trawlers, for the periods 1997-2000 (top left), 2001-2004 (top right), 2005-2008 (bottom-left) and 2009-2012 (bottom right). Trawl survey data extracted from ICES DATRAS. The domain of interest lies between $49^{\circ} 45^{\prime} \mathrm{N}$ and $61^{\circ} 45^{\prime} \mathrm{N}$, and $10^{\circ} 30^{\prime} \mathrm{W}$ and $12^{\circ} 30^{\prime} \mathrm{E}$. World borders were downloaded from http://thematicmapping.org/downloads/world_borders.php.
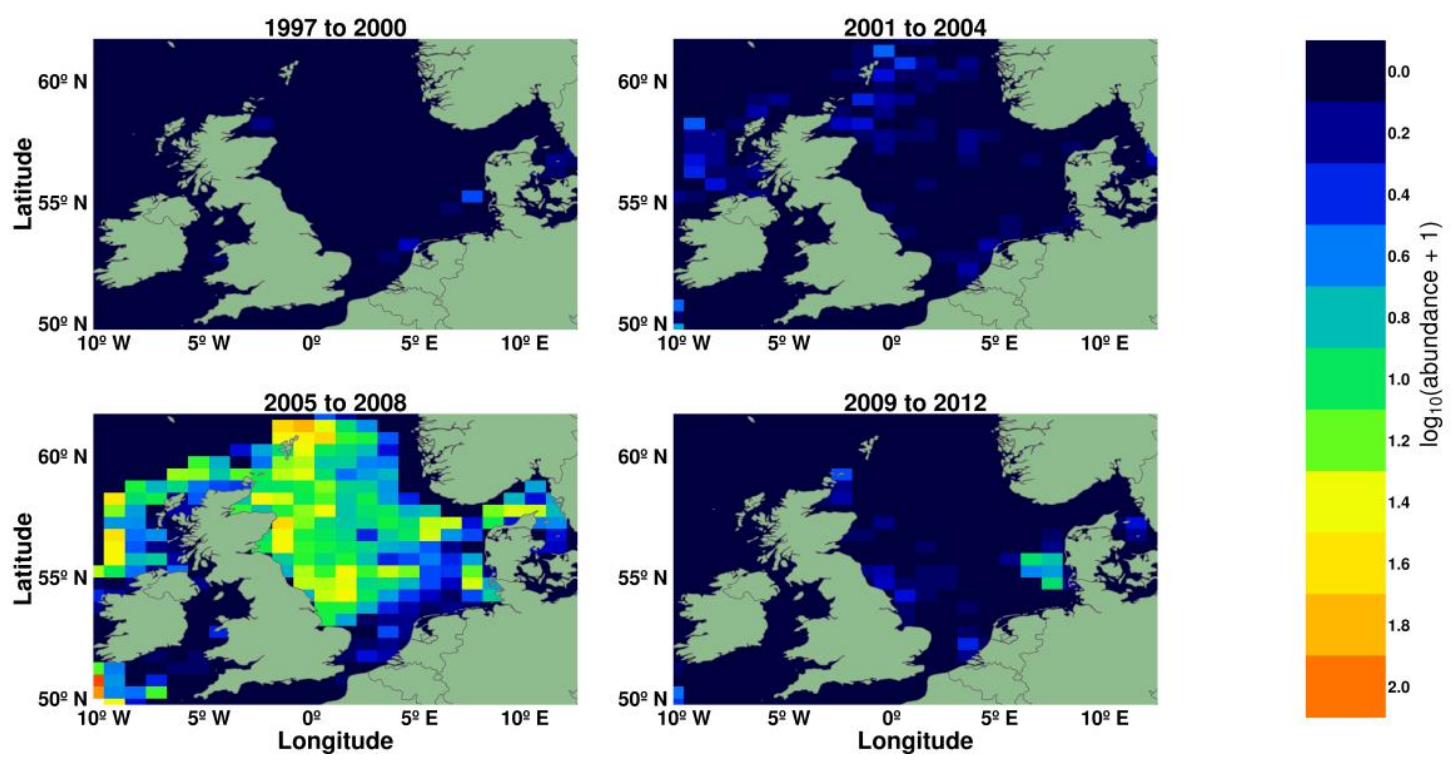